\title{
Predicting the mineral composition of dust aerosols - Part 2: Model evaluation and identification of key processes with observations
}

\author{
J. P. Perlwitz ${ }^{1,2}$, C. Pérez García-Pando ${ }^{1,2}$, and R. L. Miller ${ }^{2,1}$ \\ ${ }^{1}$ Department of Applied Physics and Applied Mathematics, Columbia University in The City of New York, NY, USA \\ ${ }^{2}$ NASA Goddard Institute for Space Studies, New York, NY, USA
}

Correspondence to: J. P. Perlwitz (jan.p.perlwitz@ nasa.gov)

Received: 17 December 2014 - Published in Atmos. Chem. Phys. Discuss.: 6 February 2015

Revised: 8 September 2015 - Accepted: 28 September 2015 - Published: 21 October 2015

\begin{abstract}
A global compilation of nearly sixty measurement studies is used to evaluate two methods of simulating the mineral composition of dust aerosols in an Earth system model. Both methods are based upon a Mean Mineralogical Table (MMT) that relates the soil mineral fractions to a global atlas of arid soil type. The Soil Mineral Fraction (SMF) method assumes that the aerosol mineral fractions match the fractions of the soil. The MMT is based upon soil measurements after wet sieving, a process that destroys aggregates of soil particles that would have been emitted from the original, undisturbed soil. The second method approximately reconstructs the emitted aggregates. This model is referred to as the Aerosol Mineral Fraction (AMF) method because the mineral fractions of the aerosols differ from those of the wet-sieved parent soil, partly due to reaggregation. The AMF method remedies some of the deficiencies of the SMF method in comparison to observations. Only the AMF method exhibits phyllosilicate mass at silt sizes, where they are abundant according to observations. In addition, the AMF quartz fraction of silt particles is in better agreement with measured values, in contrast to the overestimated SMF fraction. Measurements at distinct clay and silt particle sizes are shown to be more useful for evaluation of the models, in contrast to the sum over all particles sizes that is susceptible to compensating errors, as illustrated by the SMF experiment. Model errors suggest that allocation of the emitted silt fraction of each mineral into the corresponding transported size categories is an important remaining source of uncertainty. Evaluation of both models and the MMT is hindered by the limited number of size-resolved measurements of mineral content that sparsely sample aerosols from the major dust sources. The importance of climate processes dependent upon aerosol mineral composition shows the need for global and routine mineral measurements.
\end{abstract}

\section{Introduction}

The effect of soil dust aerosols upon climate is dependent upon the particle mineral composition (see Perlwitz et al., 2015, and references therein). Despite regional variations in soil mineral content, the radiative and chemical properties of dust aerosols are nearly always assumed by Earth system models to be globally uniform.

Claquin et al. (1999) provided the first global estimate of soil mineral content by relating it to soil type, whose regional distribution is given by the Digital Soil Map of the World (DSMW; FAO, 2007; FAO/IIASA/ISRIC/ISSCAS/JRC, 2012). Nickovic et al. (2012) and Journet et al. (2014) extended this approach by including additional measurements, soil types and minerals. Deriving the mineral composition of emitted aerosols from the soil composition presents additional challenges. Soil measurements that are the basis of global data sets are based on fully dispersive techniques like wet sieving that disturb the soil samples, breaking the aggregates found in the original soil that is subject to wind erosion (Claquin et al., 1999). Wet sieving alters the soil size distribution, replacing aggregates with a collection of smaller particles (Shao, 2001; Choate et al., 2006; Laurent et al., 2008). In the absence of measurements of the undisturbed or minimally disturbed soil, studies have assumed that the size distribution of the emitted minerals resembles that of the wetsieved parent soil (Hoose et al., 2008; Atkinson et al., 2013; Journet et al., 2014). In fact, measurements show that emitted aerosols contain aggregates of soil particles, and that the emitted size distribution is shifted toward larger diameters compared to the wet-sieved soil (e.g., Kok, 2011). This contrast between the size distribution of the fully dispersed soil and the emitted aerosol is important for the aerosol mineral content and lifetime. 
A second challenge is how to treat particles that are combinations of different minerals. For example, iron oxides are often observed as small impurities attached to particles comprised predominantly of other minerals (Scheuvens and Kandler, 2014). These mixed particles have roughly half the density of pure iron oxides, and thus carry iron farther downwind of its source.

Finally, refinement of models is challenged by limited global measurements of size-resolved aerosol composition. Many of the available measurements are from field campaigns or ship cruises of limited duration, while changes in the sampling and analysis methods through time have contributed additional uncertainty.

We address the first two challenges in a companion paper (Perlwitz et al., 2015), where we describe a new approach to estimating aerosol mineral content. We use brittle fragmentation theory (Kok, 2011) and aerosol measurements (Kandler et al., 2009) to calculate the aerosol mineral composition and its size distribution in terms of the mineral fractions of the wet-sieved soil provided by Claquin et al. (1999).

We also propose a method for mixing minerals with small impurities of iron oxides, which we call "accretions". In our model, iron oxides can travel either in pure crystalline form or as accretions internally mixed with other minerals. The distribution of the two forms of iron oxide is based on the degree of weathering that creates iron oxides in the soil (McFadden and Hendricks, 1985; Shi et al., 2011).

In this article, we compare our calculation of aerosol mineral content to a new global compilation of observations from almost sixty citations. In Sect. 2, we summarize our new modeling approach and the simulations performed with the NASA Goddard Institute for Space Studies (GISS) Earth System ModelE2, whose details can be found in the companion article (Perlwitz et al., 2015). Section 3 presents our global compilation of aerosol measurements for model evaluation (that is available in Table S1 of the Supplement), while Sect. 4 describes the evaluation approach. In Sect. 5, we show that agreement with the global compilation of aerosol measurements is improved by accounting for the modification of the mineral fractions of the parent soil during emission. Our conclusions are presented in Sect. 6 .

\section{Description of model and experiments}

Simulations are performed with the CMIP5 version of the NASA GISS Earth System ModelE2 (Schmidt et al., 2014), whose dust aerosol module is modified to incorporate individual minerals. In this section, we summarize the calculation of the size-resolved mineral fractions at emission, while describing the dust aerosol module and the configuration of the simulations. For a full description, the reader is referred to the companion paper (Perlwitz et al., 2015).

\subsection{Emitted mineral fractions: baseline and new approaches}

Two simulations are compared to our compilation of observations. The control or "baseline" simulation assumes that the emitted mineral fractions are identical to those of the wet-sieved parent soil; this calculation is referred to as the Soil Mineral Fraction (SMF) method. The soil (and thus the emitted) mineral fractions are calculated by combining the Mean Mineralogical Table (MMT; Claquin et al., 1999; Nickovic et al., 2012) with global atlases of arid soil type (Digital Soil Map of the World - DSMW; FAO, 1995, 2007) and soil texture (Hybrid STATSGO/FAO; FAO/IIASA/ISRIC/ISSCAS/JRC, 2012; NRCS Soil Survey Staff, 2012).

The MMT provides the fractional abundance for eight minerals within the clay and silt-size ranges of the soil as a function of arid soil type. For the clay-size range (whose diameters are less than $2 \mu \mathrm{m}$ ), the MMT gives the fraction of phyllosilicates (illite, kaolinite, and smectite) along with quartz and calcite. Similarly, at silt sizes (with diameters between 2 and $50 \mu \mathrm{m}$ ), the MMT gives the fraction of quartz and calcite along with feldspar, gypsum and hematite. According to the MMT, hematite is present in the soil only at silt sizes. Aerosol measurements show this mineral to be present at both clay and silt sizes (Lafon et al., 2006; Kandler et al., 2007; Engelbrecht et al., 2009; Jeong et al., 2014), so we extend the size range of emitted hematite to include clay sizes. Given the limited measurements of this mineral in soil samples, we follow Nickovic et al. (2012), and assume for simplicity that the hematite fraction at clay sizes in identical to the silt fraction provided by the MMT. In the remainder of this study, we refer to hematite more generally as "iron oxide". This is because our treatment of hematite could apply to other iron minerals like goethite that are included in more recent and refined versions of the MMT (e.g., Journet et al., 2014). Similarly, we refer to calcite more generally as "carbonate".

The mineral fractions provided by the MMT for each size category are combined with the mass fraction of each size category provided by the soil texture atlas. This gives the size-resolved mineral fractions of the wet-sieved soil at each location.

After emission, the minerals are transported within five size classes with diameters extending between 0.1 and $32 \mu \mathrm{m}$. Clay-sized particles are transported in a single bin by ModelE2. For silt particles, the MMT gives the emitted fraction of each mineral summed between 2 and $50 \mu \mathrm{m}$. It remains to distribute this fraction over the four silt categories transported by the model. For each mineral, we allocate the emitted silt fraction to the model size categories using a normalized distribution derived from measurements of dust concentration at Tinfou, Morocco (Kandler et al., 2009). In the SMF method, this allocation uses a distribution that is identical for all minerals. 
Dust at Tinfou is measured after transport from the source, when the largest particles are removed preferentially by gravitational settling. Perlwitz et al. (2015) show that our model underestimates the aerosol fraction within the largest silt-size category for all minerals at Tinfou (their Fig. 17), suggesting that emission at this size is underestimated. Because the relative size dependence of emission is normalized, underestimated emission of the largest silt particles corresponds to an overestimate of the emitted fraction of the smaller silt particles. We will return to this potential bias when we evaluate the model with observations.

The allocation of silt-sized emission within the individual size categories transported by ModelE2 is empirical and based upon measurements at only a single location. It is difficult to test the validity of this allocation at other locations, given the paucity of size-resolved measurements of mineral fractions. At diameters above roughly $20 \mu \mathrm{m}$ (below which brittle fragmentation theory provides a good fit to available measurements), the emitted size distribution is a complicated function of wind speed and soil characteristics (Alfaro and Gomes, 2001; Grini et al., 2002). However, the increase in emitted mass with increasing particle size that is exhibited at Tinfou (cf. Fig. 3 of the companion article, second panel from left) is probably a robust result of the decreasing wind speed threshold for emission as a function of diameter within this size range (Iversen and White, 1982).

Our second simulation is motivated by measurements showing significant differences between the size-resolved mineral fractions of wet-sieved soils and aerosol concentration. This simulation is referred to as the Aerosol Mineral Fraction (AMF) method to emphasize the difference between the aerosol and soil mineral fractions (in contrast to the SMF where these fractions are assumed to be identical). This difference results because wet sieving is more destructive of aggregates of soil particles than mobilization of the original, undispersed soil, where many of the aerosols are comprised of aggregates that resist complete disintegration during emission. Brittle fragmentation theory provides a physically based method for reconstructing the emitted size distribution from the distribution measured after wet sieving (Kok, 2011). The emitted silt fraction consists not only of silt particles present in the wet-sieved soil, but also aggregates that were broken during wet sieving into clay-sized fragments. In the AMF simulation, we reaggregate these fragments heuristically. For each mineral, the emitted silt fraction is comprised of silt particles in the wet-sieved soil augmented in proportion to the mineral's wet-sieved clay fraction. The degree of augmentation is prescribed through a proportionality constant $\gamma$. We set $\gamma=2$ for our reference AMF simulation, although we have not made much effort to find an optimal value of this parameter. Results with $\gamma=0$ are also shown to illustrate the physical origin of the size and regional distributions of minerals within the AMF experiment, and their contrast with respect to those of the SMF method. The only mineral that is not reaggregated in the AMF simulation is quartz, whose physical integrity is assumed to be large enough to prevent disintegration during wet sieving. One effect of reaggregation is to introduce clay minerals (illite, kaolinite and smectite) as aerosols at silt sizes. This introduction is consistent with observations (e.g., Kandler et al., 2009), and in contrast to the SMF simulation, where aerosols comprised of clay minerals are absent at silt sizes, as prescribed by the MMT (Claquin et al., 1999).

Conversely, the MMT provides the fraction of feldspar and gypsum only at silt sizes, even though aerosol measurements show that these minerals are present at both clay and silt sizes (Leinen et al., 1994; Arnold et al., 1998; Kandler et al., 2007, 2009). We combine the silt fraction of feldspar and gypsum provided by the MMT along with the emitted ratio of clay and silt-sized particles provided by brittle fragmentation theory and the normalized volume distribution derived from Kandler et al. (2009) to extend the emission of these minerals to clay sizes. Details are provided in the companion article (Perlwitz et al., 2015).

To apportion the emitted silt fraction of the AMF simulation into the ModelE2 transport categories, we combine the size distribution derived from brittle fragmentation theory (that is valid for diameters below roughly $20 \mu \mathrm{m}$ ) with the empirical volume fraction derived for each mineral. We calculate this fraction for each mineral separately (cf. Fig. 4 of the companion article), in contrast to the SMF simulation, where we use a single distribution averaged over all minerals. One consequence is that quartz emission in the AMF simulation is shifted toward larger diameters, compared to the SMF simulation. This has the effect of reducing the quartz fraction in the AMF experiment, due to the higher gravitational settling speed of larger particles.

Finally, for the AMF experiment, we allow iron oxides to be emitted not only in their pure, crystalline form, but additionally as impurities mixed with other minerals. These mixtures are important for transporting iron far from its source, because pure iron oxides are more dense and vulnerable to gravitational removal than most other minerals that contain small inclusions or accretions of iron oxides. We assume that the partitioning of iron oxides into mixtures and pure crystalline forms depends upon the soil fraction of iron oxides compared to the other minerals (as given by the MMT, including our extension to clay sizes). Soils enriched in iron oxides are assumed to be highly weathered, with a greater abundance of the pure, crystalline form (McFadden and Hendricks, 1985; Shi et al., 2011). As noted in the companion article, this is a heuristic representation of the effects of soil weathering that is more speculative than the remainder of the AMF method, and subject to future revision.

\subsection{The dust aerosol module with mineral tracers}

The dust aerosol module described by Miller et al. (2006) is modified here to represent each mineral (and its combination with iron oxides) as a separate prognostic variable 
within each of five size bins whose diameters range from 0.1 to $32 \mu \mathrm{m}$. The emitted mass of each mineral is the product of its emitted fraction, whose calculation is described above, and the total emission.

Dust sources are prescribed within topographic depressions (Ginoux et al., 2001), where vegetation is sparse and the soil particles that accumulate from erosion of the surrounding highlands are exposed to the force of the wind. Vegetation is prescribed using surface roughness (Prigent et al., 2005). Emission occurs when the surface wind speed exceeds a threshold that increases with soil moisture, following Shao et al. (1996). The surface wind includes contributions from wind gusts that are parameterized as described in Cakmur et al. (2004). In this article, we evaluate only the relative proportions of the simulated minerals; these are independent of the global magnitude of emission.

Dust removal results from wet and dry deposition. The latter includes gravitational settling and turbulent deposition in the surface layer (Wesely and Hicks, 1977; Koch et al., 1999), with settling speeds that are proportional to mineral density (Tegen and Fung, 1994). All minerals have similar densities, except for iron oxides whose density is nearly twice the value of the other minerals (Table 8; Perlwitz et al., 2015).

Wet deposition has been updated since its description in Miller et al. (2006), and is now calculated consistently with other aerosol species (Bauer and Koch, 2005; Schmidt et al., 2006). Aerosol scavenging is proportional to dust solubility and now occurs both within and below clouds where there is precipitating condensate. Scavenging is offset by reevaporation of cloud droplets and precipitation.

Measurements show that physical and chemical properties of aerosols evolve along their trajectory (cf. Baker et al., 2014). For example, phyllosilicates adsorb water (Navea et al., 2010), while heterogeneous uptake of precursor gases leads to sulfate and nitrate coatings on the particle surface. These modifications, which depend upon the mineral composition, alter the solubility and vulnerability of the dust particle to wet scavenging. We defer representation of this dependence to a future study and assume the solubility of each dust particle to be constant (50\%) and identical for each mineral (Koch et al., 1999).

We also defer calculation of radiative forcing as a function of the aerosol mineral composition. As a result, radiative feedbacks between the mineral fractions and climate are disabled.

\subsection{Simulations}

Both the SMF and AMF simulations are performed with ModelE2 at a resolution of $2^{\circ}$ latitude by $2.5^{\circ}$ longitude and 40 vertical levels. The period of 2002 through 2010 is simulated to coincide with detailed measurements at Izaña that are analyzed separately (Pérez García-Pando et al., 2015), but overlap with many of the measurements used for evaluation in the present study. The horizontal winds at each level of the model are relaxed every $6 \mathrm{~h}$ toward the NCEP reanalyzed values (Kalnay et al., 1996). Relaxation occurs at all model levels (up to $10 \mathrm{hPa}$ ) with the globally uniform timescale of $100 \mathrm{~s}$. Relaxation increases the resemblance of model transport to that observed so that the mineral fractions simulated at the observing sites are more strongly dependent upon our treatment of aerosol emission and removal than the calculated transport. Similarly, we prescribe sea surface temperature and sea ice based upon observed values (e.g., Rayner et al., 2003).

\section{Observations for model evaluation}

We compiled measurements of mineral fractions of dust aerosols from almost sixty studies published between the 1960s and the present day that are described in Table 1 and available in Table S1 of the Supplement. Roughly one-third of the studies are in common with a recent compilation focusing on North African sources by Scheuvens et al. (2013). Our compilation includes measurements of dust concentration and deposition, both from land stations and ship cruises. A few studies provide measurements of dust deposited in permanent snow fields (Windom, 1969; Gaudichet et al., 1992; Zdanowicz et al., 2006). Measurements are not equally distributed over all dust source regions, and mostly sample dust transported from North Africa, the Middle East and Asia (Fig. 1). Only two studies provide measurements downwind of southern African sources (Aston et al., 1973; Chester et al., 1971). No studies were found for dust from North America, while only one site is affected by the Australian dust plume (Windom, 1969). Generally, most of the measurements for aerosol mineral composition are in the Northern Hemisphere and there is underrepresentation of the Southern Hemisphere. Also, many of the measurements in earlier decades were confined to the relative proportions of phyllosilicates.

Methods to determine the mineral composition of dust aerosols have varied over time, and the measurements in our compilation that are based on various instruments and analytical methods contain different biases and uncertainties. Systematic studies of the mineral composition of atmospheric soil dust started in the 1960s, beginning with Delany et al. (1967), who intended to investigate cosmic dust. The mineral composition of airborne dust was usually determined from samples collected on suspended nylon mesh over land or ships (e.g., Prospero and Bonatti, 1969; Goldberg and Griffin, 1970; Parkin et al., 1970; Chester and Johnson, 1971b; Tomadin et al., 1984). Typically, the collection efficiency of the mesh was assumed to be $50 \%$ (Prospero and Bonatti, 1969), but the true value depends upon particle size and wind velocity (Chester and Johnson, 1971a). Parkin et al. (1970) determined a collection efficiency of $100 \%$ for spherical particles with densities of $3 \mathrm{~g} \mathrm{~cm}^{-3}$ and particle diameters greater than $7 \mu \mathrm{m}$, with the efficiency decreasing to 
Table 1. List of literature references for mineral fraction measurements (predicted with ModelE2: M - mica/illite/muscovite, $\mathrm{K}$ - kaolinite, $\mathrm{S}$ - smectite, C - carbonates, Q - quartz, F - feldspar, I - iron oxides, G - gypsum; other minerals not predicted: O) with specific information about months of measurements with size range, geographical coordinates, and time range of measurements.

\begin{tabular}{|c|c|c|c|c|}
\hline Reference & Minerals & Size range & Location & Time range \\
\hline Adedokum et al. (1989) & M K Q F O & Total & Ile-Ife, Nigeria & $\begin{array}{l}\text { Jan-Feb } 1984 \\
\text { Jan-Feb } 1985\end{array}$ \\
\hline Alastuey et al. (2005) & M K CQFGO & Total & $\begin{array}{l}\text { Izaña and Sta. Cruz de Tenerife, } \\
\text { Canary Islands, Spain }\end{array}$ & $29 \mathrm{Jul} 2002$ \\
\hline Al-Awadhi and AlShuaibi (2013) & M C QFO & Total & $\begin{array}{l}10 \text { sites in Kuwait } \\
\text { City, Kuwait }\end{array}$ & $\begin{array}{l}\text { Mar 2011-Feb } 2012 \\
\text { (monthly) }\end{array}$ \\
\hline $\begin{array}{l}\text { Al-Dousari and Al-Awadhi } \\
\text { (2012) }\end{array}$ & $\mathrm{M}+\mathrm{K}+\mathrm{S} \mathrm{CQFO}$ & Total & $\begin{array}{l}10 \text { locations in the Arabian Penin- } \\
\text { sula }\end{array}$ & $\begin{array}{l}\text { Nov 2006-Dec } 2007 \\
\text { (monthly) }\end{array}$ \\
\hline Al-Dousari et al. (2013) & $\mathrm{M}+\mathrm{K}+\mathrm{S} \mathrm{CQFO}$ & Total & 11 global locations & $\begin{array}{l}\text { Jan 2007-Dec } 2007 \\
\text { (monthly) }\end{array}$ \\
\hline Arnold et al. (1998) & M K S Q F O & $\begin{array}{l}<2 \mu \mathrm{m} \\
2-20 \mu \mathrm{m}\end{array}$ & $\begin{array}{l}\text { 1: north of Hawaii } \\
\text { 2: northeastern } \\
\text { Pacific }\end{array}$ & $\begin{array}{l}\text { 1: May } 1986 \\
\text { 2: Mar-Apr } 1987\end{array}$ \\
\hline Aston et al. (1973) & $\begin{array}{l}\text { 1: M K S O; } \\
\text { 2: C Q O }\end{array}$ & $\begin{array}{l}1:<2 \mu \mathrm{m} \\
2: \text { Total }\end{array}$ & $\begin{array}{l}\text { Eastern North and South Atlantic, } \\
\text { Indian Ocean, } \\
\text { Sea of China }\end{array}$ & Jul 1971-Nov 1971 \\
\hline Avila et al. (1997) ${ }^{a}$ & M K S C Q F O & Total & $\begin{array}{l}\text { Montseny Mountains, } \\
\text { Spain }\end{array}$ & Nov 1984-Mar 1992 \\
\hline Awadh (2012) & C Q F G O & Total & Baghdad, Iraq & Mar-Jun 2008 \\
\hline Chester and Johnson (1971a) & M K S O & $<2 \mu \mathrm{m}$ & Eastern Atlantic & 6-13 Nov 1970 \\
\hline Chester and Johnson (1971b) & M K S O & $<2 \mu \mathrm{m}$ & Eastern Atlantic & 22 Apr-5 May 1969 \\
\hline Chester et al. (1971) & M K S O & $<2 \mu \mathrm{m}$ & Eastern Atlantic & Jul-Aug 1970 \\
\hline Chester et al. (1972) & M K S O & $<2 \mu \mathrm{m}$ & Eastern Atlantic & 17-28 Mar 1971 \\
\hline Chester et al. (1977) & $\begin{array}{l}\text { 1: M K S O } \\
\text { 2: Q C }\end{array}$ & $\begin{array}{l}1:<2 \mu \mathrm{m} \\
2: \text { total }\end{array}$ & Eastern Mediterranean & $\begin{array}{l}\text { Summer 1972, } \\
\text { Spring } 1975\end{array}$ \\
\hline Chester et al. (1984) & M K S O & $<2 \mu \mathrm{m}$ & Tyrrhenian Sea & $8-25$ Oct 1979 \\
\hline Delany et al. (1967) & $\begin{array}{l}\text { M K S Q } \\
\text { O }\end{array}$ & $<2 \mu \mathrm{m}$ & Barbados & Oct 1965-Jan 1966 \\
\hline Díaz-Hernández et al. (2011) & M K S C Q F G O & Total & Granada Depression, Spain & 1992 \\
\hline Enete et al. (2012) & $\begin{array}{l}\text { 1: M K Q F 2: M K QF } \\
\text { I O }\end{array}$ & $\begin{array}{l}1:<2 \mu \mathrm{m} \\
2: 2-50 \mu \mathrm{m}\end{array}$ & Two sites in Enugu, Nigeria & $\begin{array}{l}\text { Oct 2009-Apr 2010, } \\
\text { Oct 2010-Apr } 2011 \\
\text { (weekly) }\end{array}$ \\
\hline Engelbrecht et al. (2009) & $\mathrm{M}+\mathrm{K}+\mathrm{S}^{\mathrm{b}} \mathrm{CQ}$ F I O & $<10 \mu \mathrm{m}$ & $\begin{array}{l}14 \text { sites in Central and West Asia } \\
\text { and } 1 \text { site in Djibouti }\end{array}$ & $2005-2007$ \\
\hline Engelbrecht et al. (2014) & $\begin{array}{l}\mathrm{M}+\mathrm{K}+\mathrm{S}^{\mathrm{b}} \mathrm{CQ}^{\mathrm{c}} \mathrm{G} \\
\mathrm{O}\end{array}$ & $<2.5 \mu \mathrm{m}$ & $\begin{array}{l}\text { Las Palmas de Gran Canaria, } \\
\text { Spain }\end{array}$ & $\begin{array}{l}12 \text { Jan }-27 \text { Nov } 2010 \\
\text { ( } 2 \text { to } 13 \text { days) }\end{array}$ \\
\hline Falkovich et al. (2001) & C Q F G & Total & Tel Aviv, Israel & 16 Mar 1998 \\
\hline Ferguson et al. (1970) & M K S O & $<2 \mu \mathrm{m}$ & Northeastern Pacific & Apr 1969 \\
\hline Fiol et al. (2005) ${ }^{d}$ & M K CQFO & Total & Palma de Mallorca, Spain & $\begin{array}{l}6 \text { May 1988-27 Apr } \\
1999\end{array}$ \\
\hline Formenti et al. (2008) & M K C Q F & $<40 \mu \mathrm{m}$ & Banizoumbou, Niger & 13 Jan-13 Feb 2006 \\
\hline Game (1964) & C Q F I O & Total & Eastern Atlantic & 6 Feb 1962 \\
\hline Ganor (1991) & M K O & $<10 \mu \mathrm{m}$ & $\begin{array}{l}\text { Tel Aviv and } \\
\text { Jerusalem, Israel }\end{array}$ & $1968-1987$ \\
\hline Ganor et al. (2000) & $\begin{array}{l}\text { 1: M K S O } \\
\text { 2: C Q F }\end{array}$ & $\begin{array}{l}1:<2 \mu \mathrm{m} \\
2:>=2 \mu \mathrm{m}\end{array}$ & $\begin{array}{l}16 \text { locations around Lake Kin- } \\
\text { neret, Israel }\end{array}$ & Jan 1993-May 1997 \\
\hline
\end{tabular}


Table 1. Continued.

\begin{tabular}{|c|c|c|c|c|}
\hline Reference & Minerals & Size range & Location & Time range \\
\hline Gaudichet et al. (1989) & M K S C Q F O & Total & Amsterdam Island, TAAF & $\begin{array}{l}\text { 15-26 May 1984, 7- } \\
30 \text { Jul 1984, 5-29 Sep } \\
1984\end{array}$ \\
\hline Gaudichet et al. (1992) & M K S O & $<2 \mu \mathrm{m}$ & $\begin{array}{l}\text { 1: Vostok, } \\
\text { 2: South Pole }\end{array}$ & $\begin{array}{l}\text { 1: } 1927 \\
\text { 2: } 1955\end{array}$ \\
\hline Glaccum and Prospero (1980) & M K C Q F O & Total & $\begin{array}{l}\text { Sal Island, Cape } \\
\text { Verde; Barbados; } \\
\text { Miami, Florida }\end{array}$ & Jul-Aug 1974 \\
\hline Goldberg and Griffin (1970) & M K S O & $<2 \mu \mathrm{m}$ & $\begin{array}{l}\text { 1: Bay of Bengal } \\
\text { 2: Waltair, India }\end{array}$ & $\begin{array}{l}\text { 1: May } 1968 \\
\text { 2: Jan } 1969\end{array}$ \\
\hline Jeong (2008) & M K S C Q F O & $<10 \mu \mathrm{m}$ & Seoul, Korea & $\begin{array}{l}\text { Spring 2003, } \\
2004,2005\end{array}$ \\
\hline Jeong and Achterberg (2014) & $\mathrm{M}+\mathrm{S}$ K C Q F G O & $<60 \mu \mathrm{m}$ & $\begin{array}{l}\text { 1: Deokjeok Island, } \\
\text { Korea } \\
\text { 2: Andong, Korea } \\
\text { 3: São Vicente, Cape Verde }\end{array}$ & $\begin{array}{l}\text { 1: } 31 \text { Mar 2012 } \\
\text { 2: } 16-17 \text { Mar } 2009^{\mathrm{f}} \text {, } \\
\text { 20 Mar } 2010^{\mathrm{f}}, 18 \mathrm{Mar} \\
2014^{\mathrm{f}} \\
\text { 3: 28-31 Dec 2007, 18- } \\
\text { 23 Jan 2008 }\end{array}$ \\
\hline Jeong et al. (2014) & $\mathrm{M}+\mathrm{S}$ K C Q F I G O & $\begin{array}{l}\text { 1: five size bins } \\
\text { up to } 60 \mu \mathrm{m} \\
2:<60 \mu \mathrm{m}\end{array}$ & $\begin{array}{l}\text { 1: Deokjeok Island, } \\
\text { Korea } \\
\text { 2: Andong, Korea }\end{array}$ & $\begin{array}{l}\text { 1: } 31 \text { Mar 2012- } \\
1 \text { Apr } 2012^{\mathrm{f}} \\
2: 20 \operatorname{Mar} 2010^{\mathrm{f}} \\
1 \text { May } 2011^{\mathrm{f}}\end{array}$ \\
\hline Johnson (1976) & $\begin{array}{l}\text { 1: M S O } \\
\text { 2: } \mathrm{M}+\mathrm{K}+\mathrm{S}^{\mathrm{g}} \\
\text { QF }\end{array}$ & $\begin{array}{l}1:<2 \mu \mathrm{m} \\
2: \text { total }\end{array}$ & Three in the Atlantic; Barbados & $\begin{array}{l}\text { Dec 1898; Oct 1965; } \\
\text { Mar 1971 }\end{array}$ \\
\hline Kandler et al. (2007) & M C Q F I G O & $\begin{array}{l}\text { Eight size bins } \\
0.05 \text { to } 20 \mu \mathrm{m}^{\mathrm{h}}\end{array}$ & $\begin{array}{l}\text { Izaña, Tenerife, Canary Islands, } \\
\text { Spain }\end{array}$ & $\begin{array}{l}\text { 13-23 Jul 2005, 6-8 } \\
\text { Aug } 2005\end{array}$ \\
\hline Kandler et al. (2009) & M K C Q F I G O & $\begin{array}{l}10 \text { size bins } \\
0.1 \text { to } 250 \mu \mathrm{m}^{\mathrm{i}}\end{array}$ & Tinfou, Morocco & 13 May-7 Jun 2006 \\
\hline Kandler et al. (2011) & $\mathrm{M}^{\mathrm{j}} \mathrm{K} \mathrm{S} \mathrm{C} \mathrm{Q} \mathrm{F} \mathrm{G} \mathrm{O}$ & Total & Praia, Cap Verde & $\begin{array}{l}\begin{array}{l}14 \text { Jan-9 } \\
\text { (daily) }\end{array} \\
\text { Feb } 2008\end{array}$ \\
\hline Khalaf et al. (1985) & $\mathrm{M}+\mathrm{S}$ K C Q F G O & $<4 \mu \mathrm{m}$ & Eight locations in Kuwait & Apr 1979-Mar 1980 \\
\hline Leinen et al. (1994) & M K S Q F O & $\begin{array}{l}1:<2 \mu \mathrm{m} \\
2: 2-20 \mu \mathrm{m}\end{array}$ & Northwestern and eastern Pacific & Sep 1977-Oct 1979 \\
\hline Lu et al. (2006) & M K S Q F O & $<10 \mu \mathrm{m}$ & Beijing, China & Apr 2002-Mar 2003 \\
\hline Menéndez et al. (2007) & $\mathrm{M} \mathrm{K}^{\mathrm{k}} \mathrm{C} \mathrm{Q} F \mathrm{O}$ & Total & $\begin{array}{l}\text { Gran Canaria, Canary Islands, } \\
\text { Spain }\end{array}$ & $\begin{array}{l}31 \text { Oct 2002-23 Oct } \\
2003\end{array}$ \\
\hline Møberg et al. (1991) & M K S Q F I O & $<2 \mu \mathrm{m}$ & Zaria, Nigeria & Nov 1984-Mar 1985 \\
\hline O’Hara et al. (2006) & M K C Q F G O & Total & $\begin{array}{l}\text { 1: northern Libya } \\
\text { 2: southern Libya }\end{array}$ & Jun 2000-May 2001 \\
\hline Parkin et al. (1970) & M S Q O & Total & North Atlantic & $\begin{array}{l}\text { Jan } 1969 \text { and } \\
\text { Aug } 1969\end{array}$ \\
\hline Parkin et al. (1972) & M S Q O & Total & Central Atlantic & Feb-Mar 1971 \\
\hline Prospero and Bonatti (1969) & M K S Q F O & $<20 \mu \mathrm{m}$ & Eastern Pacific & Spring 1967 \\
\hline Prospero et al. (1981) & M K Q F C I G O & Total & $\begin{array}{l}\text { 1: Cayenne } \\
\text { 2: Dakar, Barbados, } \\
\text { Cayenne }\end{array}$ & $\begin{array}{l}\text { 1: Dec } 1977- \\
\text { Apr } 1980 \\
\text { 2: } 21-27 \text { Mar } 1978\end{array}$ \\
\hline Queralt-Mitjans et al. (1993) & M K C Q F G O & Total & $\begin{array}{l}\text { Seven locations at the Filabres } \\
\text { range, Spain }\end{array}$ & $\begin{array}{l}\text { Nov-Dec 1989, } \\
\text { Mar-May } 1990\end{array}$ \\
\hline Rashki et al. (2013) & M C Q F G O & $<75 \mu \mathrm{m}$ & $\begin{array}{l}\text { Two locations in the Sistan } \\
\text { region, Iran }\end{array}$ & Aug 2009-Aug 2010 \\
\hline
\end{tabular}


Table 1. Continued.

\begin{tabular}{|c|c|c|c|c|}
\hline Reference & Minerals & Size range & Location & Time range \\
\hline Shao et al. (2008) & $\begin{array}{l}\text { 1: } \mathrm{MK} \mathrm{S}^{\mathrm{m}} \mathrm{O} \\
\text { 2: } \mathrm{M}+\mathrm{K}+\mathrm{S} \text { C Q F G } \\
\mathrm{O}\end{array}$ & $\begin{array}{l}1:<2 \mu \mathrm{m} \\
2: \text { total }\end{array}$ & Beijing, China & $\begin{array}{l}\text { 1+2: } 17 \text { Apr 2006, } \\
\text { spring } 2006 \\
\text { 2: spring 2004, } \\
\text { 2005 }\end{array}$ \\
\hline Shen et al. (2006) & M K C Q F O & Total & Dunhuang, China & $\begin{array}{l}\text { Spring } 2001 \text { and } \\
2002\end{array}$ \\
\hline Shen et al. (2009) & M C Q F O & Total & $\begin{array}{l}\text { Five locations in desert regions of } \\
\text { China }\end{array}$ & $\begin{array}{l}\text { Spring } 2001 \text { and } \\
2002\end{array}$ \\
\hline Shi et al. (2005) & $\begin{array}{l}\text { 1: M K S } \\
\text { O } \\
\text { 2: M+K+S C Q F I } \\
\text { G } \\
\text { 3: M+K+S C Q F O }\end{array}$ & $\begin{array}{l}1:<2 \mu \mathrm{m} \\
2:<10 \mu \mathrm{m} \\
3: \text { total }\end{array}$ & Beijing, China & $\begin{array}{l}6 \text { Apr } 2000 \text { and } \\
20 \text { Mar } 2002 \\
(1 \text { and } 2 \text { only) }\end{array}$ \\
\hline Skonieczny et al. (2013) & $\mathrm{MKS} \mathrm{O}^{\mathrm{n}}$ & $<30 \mu \mathrm{m}$ & Mbour, Senegal & $\begin{array}{l}23 \text { Feb 2006-27 Mar } \\
2009 \text { (weekly) }\end{array}$ \\
\hline Tomadin et al. (1984) & M K S O & $<2 \mu \mathrm{m}$ & $\begin{array}{l}\text { 1: central Mediterranean } \\
\text { 2: central Mediterranean } \\
\text { 3: Scilla, Messina, } \\
\text { Bologna }\end{array}$ & $\begin{array}{l}\text { 1: Mar } 1981 \\
\text { 2: Oct } 1981- \\
\text { Nov } 1981 \\
\text { 3: Mar } 1981\end{array}$ \\
\hline Windom (1969) & M K S Q F O & Total & 5 permanent snow fields on planet & Before 1969 \\
\hline Zdanowicz et al. (2006) & M K S O & Total & $\begin{array}{l}\text { St. Elias Mountains, } \\
\text { Canada }\end{array}$ & 16 Apr 2001 \\
\hline Zhou and Tazaki (1996) & $\begin{array}{l}\mathrm{I}+\mathrm{K}+\mathrm{S} \mathrm{C} \\
\mathrm{Q} \mathrm{GO}\end{array}$ & Total & Matsue, Japan & $\begin{array}{l}\begin{array}{l}\text { Oct 1992-Sep } 1993 \\
\text { (weekly) }\end{array} \\
\end{array}$ \\
\hline
\end{tabular}

$\overline{\mathrm{a}}$ only Red Rain events; ${ }^{\mathrm{b}}$ may contain chlorite $;{ }^{\mathrm{c}}$ may contain rutile or pyrolusite; ${ }^{\mathrm{d}}$ only Red Rain events; ${ }^{\mathrm{e}}$ all minerals: percentage of refractive surface (XRD); ${ }^{\mathrm{f}}$ dust event; ${ }^{\mathrm{g}}$ includes chlorite; ${ }^{\mathrm{h}}$ used here: $1-2.5,2.5-5,5-10$, and $10-20 \mu \mathrm{m}$ ranges; ${ }^{\mathrm{i}}$ interpolated to ModelE2 size bins; ${ }^{\mathrm{j}}$ as part of mixed layer illite-smectite; ${ }^{\mathrm{k}}$ kaolinite-chlorite; ${ }^{1}$ all minerals: from maximum and minimum value; ${ }^{\mathrm{m}}$ as part of mixed-layer illite-smectite, ${ }^{\mathrm{n}}$ mineralogy of aluminosilicates only.

$50 \%$ for diameters of $2 \mu \mathrm{m}$ and null collection of particles with diameters below $0.5 \mu \mathrm{m}$. Thus, mesh collection introduces a bias towards larger dust particles, and potentially overestimates the fraction of minerals such as quartz, whose abundance peaks at large particle sizes. Other studies analyzed dust deposited on ship decks (e.g., Game, 1964; Johnson, 1976) or over land (e.g., Goldberg and Griffin, 1970; Tomadin et al., 1984; Khalaf et al., 1985; Adedokum et al., 1989; Skonieczny et al., 2011).

Since the 1990s, airborne dust has been more commonly sampled with other instruments, like high-volume air samplers (e.g., Zhou and Tazaki, 1996; Alastuey et al., 2005; Shi et al., 2005; Jeong, 2008; Shen et al., 2009) or low-volume air samplers (e.g., Gao and Anderson, 2001; Engelbrecht et al., 2009). These samples extract dust from the air with polycarbonate or quartz microfibre filters (Shi et al., 2005), cellulose filters (Jeong, 2008), or other filters (Engelbrecht et al., 2009). The finest aerosol particles can get trapped in the quartz fibre filters before the sample is treated for the mineral analysis, a source of collection inefficiency and uncertainty (Alastuey et al., 2005).

The relative mass fractions of the collected minerals are often derived from X-ray diffraction (XRD) spectra (e.g., Prospero and Bonatti, 1969; Alastuey et al., 2005; Shi et al.,
2005; Skonieczny et al., 2011). The wavelengths of spectral peaks give information about elemental and mineral composition, while the mass fraction relative to other minerals is determined by area under the peak. Characterization of the area (rather than the peak) increases the sensitivity to particle diameters less than $10 \mu \mathrm{m}$ that cause peak broadening (Glaccum and Prospero, 1980).

$\mathrm{XRD}$ analysis is most effective for minerals with a regular crystal structure whose spectral peaks are well defined. However, certain minerals like phyllosilicates consist of varying amounts of amorphous material whose mass is difficult to quantify using XRD (Formenti et al., 2008; Kandler et al., 2009). Among the various minerals considered in this study, the fraction of smectite is one of the most difficult to estimate. Its spectral peaks are small and can lie within the noise level of the XRD analysis (Glaccum and Prospero, 1980). This has been interpreted as the result of low concentration and poor crystallization (Leinen et al., 1994). This is additionally due to the frequent interleaving of smectite with illite and other minerals like chlorite, both in soils (Sŕodon, 1999) and aerosols (Shi et al., 2005; Lu et al., 2006), which can lead to misidentification of the individual phyllosilicates. As a consequence, smectite is occasionally reported only in combination with illite (Shi et al., 2005; Shao et al., 2008). 


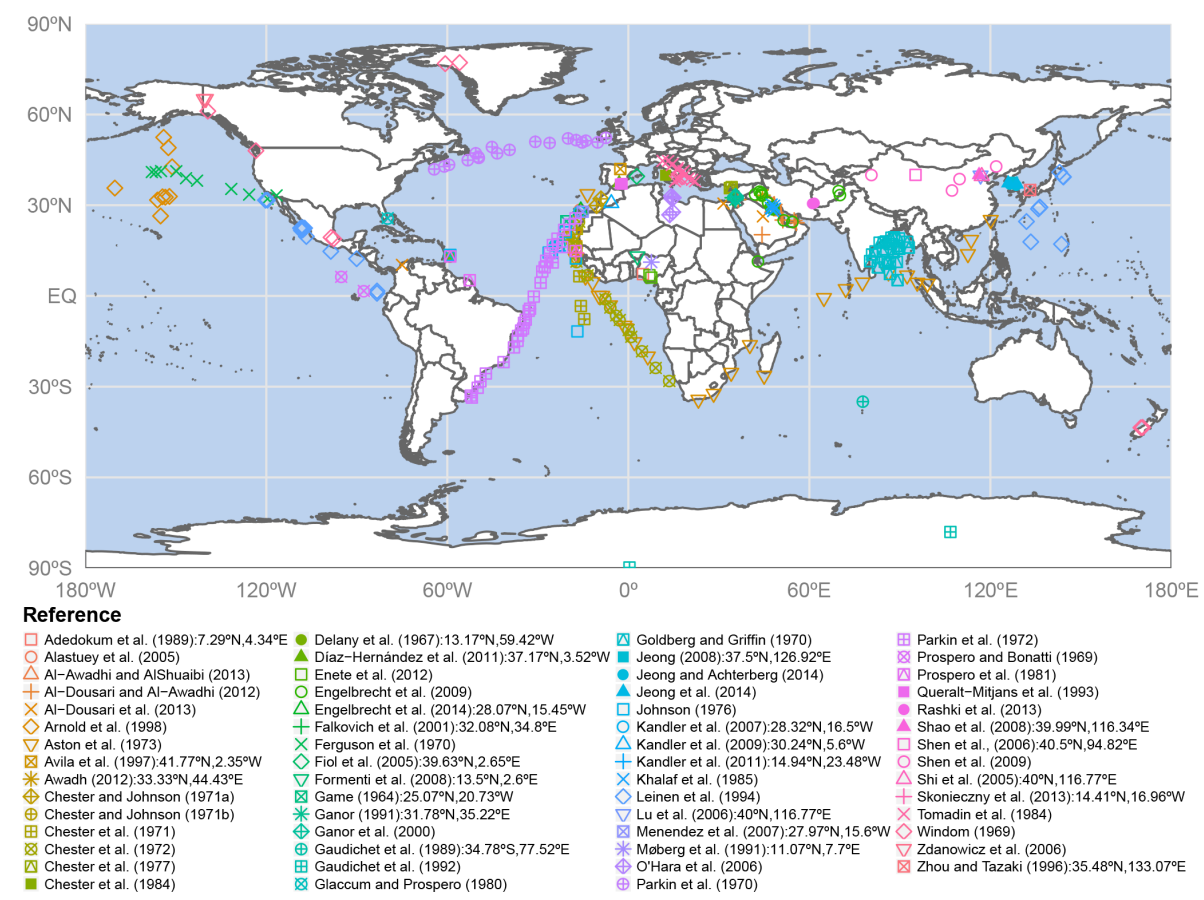

Figure 1. Locations of measured mineral fractions compiled from the literature used for the evaluation of the simulations. References with geographical coordinates in the legend provide measurements only for this single location; otherwise, references provide measurements for multiple locations. See Table 1 and Table S1 in the Supplement for more information.

The composition of airborne particles is increasingly studied by scanning electron microscope (SEM) images of individual particles along with statistical cluster analysis of elemental composition (e.g., Gao and Anderson, 2001; Lu et al., 2006; Kandler et al., 2009; Engelbrecht et al., 2009). Both XRD and SEM measurements are disproportionately sensitive to composition on the particle surface, which may include coatings resulting from chemical reactions with other species, compared to the particle interior.

All the observations used for our evaluation are based on measurements of the mineral fractions of dust aerosols at the surface. A few studies also provide aircraft measurements (Formenti et al., 2008; Klaver et al., 2011; Formenti et al., 2014b). Those data are not taken into consideration but will be included in future evaluation of simulated vertical profiles.

Because of the difficulty of comparing the uncertainty of different measurement methods, we weight all observations equally. As prognostic models of mineral composition become more common, we hope that mineral identification within aerosol samples becomes more uniform and routine.

\section{Method of evaluation}

A challenge for model evaluation is the difference in record length between climate model output and the mineral observations. Deposition is measured over periods as short as a week. Measurements of surface concentration are based mostly on daily sampling, with reported values derived from a few days. In contrast, the output from our model simulations consists of a continuous stream of data, from which monthly averages are calculated. Note that even though the model output could be archived at higher frequencies, e.g., every model day, a large discrepancy between the small sample sizes of many of the measurements and large samples from the model simulations would persist. The mineral fractions that we use for evaluation reflect the composition of the soil at the source region. These fractions are probably more consistent than the absolute concentration of the separate minerals used to form this ratio, at least in those remote regions where a single source dominates the supply. Thus, measurements of mineral fractions from a few days may be representative of the entire month. Closer to a source, the mineral fractions may be more variable, with episodic increases of quartz and other minerals that are abundant at large diameters during dust storms (cf. Fig. 10 from Kandler et al., 2009). An evaluation of the uncertainty created by the limited measurement duration is planned for the future using daily model output.

For each reference providing measurements, we calculate a time average that can be compared to the model output. In some cases, we estimate a monthly average using daily measurements that are available for only a subset of the month. Our simulations cover only the 9 years between 2002 and 2010, but some of the measurements date back to the 1960s. Our evaluation assumes that multi-decadal variability in the 
mineral fractions of dust aerosols at individual locations is small compared to the fractions themselves. A more thorough discussion of the sampling uncertainty in our comparison between the measurements and model is provided in Appendix A.

We simulate only eight minerals in our model. However, measurements may include additional minerals that are not simulated. Other measurements may not include all of the simulated minerals. (For example, Kandler et al. (2009) do not distinguish smectite from the other phyllosilicates.) To make the measured and simulated mineral fractions comparable, we recalculate the fractions at each individual data point using only minerals present in both the measurements and the model. We caution that this renormalization can be misleading if some minerals that contribute to the total dust mass were simply not reported. (The mineral fraction measurements compiled in Table S1 of the Supplement include all reported minerals, including both those simulated and those omitted from the ModelE2.)

To account for different size ranges of the model and measurements, we interpolate the mass fractions from the model size bins to the size range of the measurements. For measurements of total suspended particles (TSP), we compare to the sum over the entire model size range. Since this range extends only to $32 \mu \mathrm{m}$, this can lead to a positive bias in the observations for minerals like quartz that are more abundant at larger particle sizes, particularly at measurement locations near dust sources.

We compare the measured and simulated mineral fractions and ratios using scatterplots. We calculate the normalized bias (nBias) and normalized root mean squared error (nRMSE). Normalization was done by dividing the statistic by the average of the observed values used in each scatterplot. The number of paired data points $(N)$ from the measurements and the simulations is also provided with each scatterplot. These summary statistics are computed without weighting: for example, with respect to the number of measurements used to compute the average value of each study. Such precision seems illusory given the incommensurate analytical uncertainty of different measurement types discussed in Sect. 3. Our goal is not to provide a detailed statistical analysis using these metrics, but to help identify robust improvement or deterioration of the AMF results compared to the SMF method.

Our evaluation compares measurements from a specific location to the value at the corresponding grid box. In the case of ship cruises, we use the average along the cruise trajectory within each ocean, forming a model average with the corresponding sequence of grid boxes. Our comparison assumes that the grid size of the model is sufficient to resolve spatial variations of the measurements. This is not always the case, particularly near dust sources that are often geographically isolated, resulting in strong spatial contrasts of concentration (e.g., Prospero et al., 2002). For example, we discuss below measurements by Engelbrecht et al. (2009) and Al-Dousari and Al-Awadhi (2012), who find large variations in mineral ratios with respect to quartz at nearby locations in the Middle East. Some of these measurements are within a single grid box and thus impossible to resolve with the model.

\section{Evaluation of the predicted mineral fractions}

In a companion paper (Perlwitz et al., 2015), it is shown that the AMF method brings the model into better agreement with size-dependent surface concentration derived from measurements at Tinfou, Morocco (Kandler et al., 2009). The AMF method reproduces the observed large mass fraction of phyllosilicates at silt sizes and reduces the quartz fraction, in contrast to the SMF experiment (Fig. 16 in Perlwitz et al., 2015). The AMF method also introduces feldspar and gypsum at clay sizes, despite their exclusion from the MMT and SMF experiment. Both experiments underestimate all mineral fractions at the largest model size category, possibly because the emitted silt is distributed among the corresponding four model size categories using size-resolved measurements following transport from the source and after removal of the largest particles by gravitational settling, as described in Sect. 2.1.

Below, we extend the evaluation of both methods to the global scale. We calculate mineral fractions that are the ratio of the mass of each mineral to the sum over all minerals. Alternatively, we consider the ratio of specific mineral pairs. The mineral mass is derived from surface concentration or deposition, depending upon the measured quantity.

\subsection{Seasonal cycle of mineral fractions}

Only a few locations have measurements at multiple times throughout the year, and these are generally insufficient to resolve the seasonal cycle. We use these measurements for comparison to the model that at some locations exhibits a seasonal shift in the predominant mineral.

Figure 2 compares the simulated seasonal cycle of the phyllosilicate fraction to measurements at Barbados (Delany et al., 1967) and the Pacific (Leinen et al., 1994; Arnold et al., 1998). The fraction is defined relative to the sum of minerals that are present in both the model and measurements within the same size class. At Barbados, the illite-smectite and kaolinite fractions calculated by the models show contrasting seasonal cycles, driven by the seasonal shift of the Intertropical Convergence Zone (ITCZ) and the trade winds over the North Atlantic (Moulin et al., 1997). During summer, dust is preferentially transported from northern African sources enriched in illite and smectite, in contrast to winter, when dust is emitted from sources farther south containing higher amounts of kaolinite (Caquineau et al., 1998). Both experiments calculate mineral fractions that are consistent with the measurements, although the uncertainty due to the small sample size hampers a robust evaluation. 

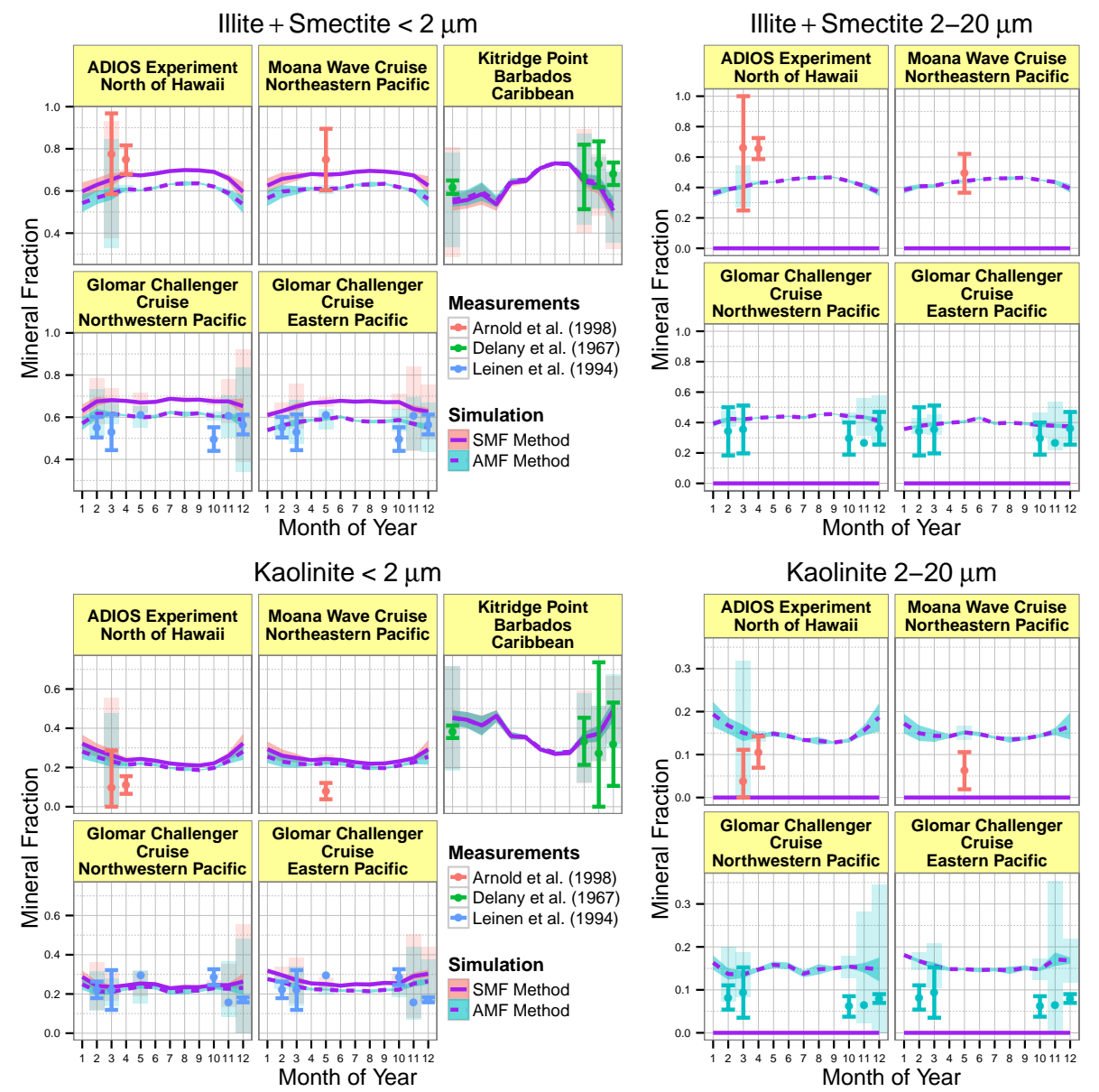

Figure 2. Annual cycle of illite plus smectite and kaolinite fractions for diameters less than $2 \mu \mathrm{m}$ and from 2 to $20 \mu \mathrm{m}$ as measured and simulated by the SMF and AMF methods. The vertical error bars, shaded ribbons, and shaded bars represent the $95 \%$ confidence intervals of the measurements, the simulations (based on monthly SDs), and the simulations sampled at the frequency of the measurements, respectively.

Over the Pacific, both the SMF and the AMF experiments show similar illite-smectite and kaolinite fractions at clay sizes that are consistent with the observations. The slightly smaller AMF fraction of phyllosilicates results from the addition of feldspar and gypsum at clay sizes that comes at the expense of the phyllosilicate fraction. (This difference between the AMF and SMF treatments of phyllosilicates is obscured in the Barbados measurements because feldspar and gypsum are not measured and are thus excluded from our reconstruction of the total dust mass at clay sizes.) At silt sizes, the simulated AMF fraction of phyllosilicates that is observed at the Pacific locations is entirely absent in the SMF experiment, highlighting the importance of reconstructing the emitted phyllosilicate mass comprised of soil aggregates that are almost totally disintegrated during wet sieving of the soil samples. There is the suggestion that the kaolinite fraction is overestimated by the model at both clay and silt sizes, a discrepancy that is found at other locations, as will be discussed below.
Figure 3 compares the simulated seasonal cycle of feldspar and quartz in the Pacific to ship measurements. Both the AMF and SMF methods predict similar quartz fractions in the clay size range that are close to the observed values. However, the AMF method is in much better agreement with the measurements at silt diameters, whereas the SMF experiment overestimates the quartz fraction by nearly fourfold. Figures 2 and 3 show that the SMF overestimation of the quartz fraction at silt sizes at the expense of phyllosilicates is not limited to Tinfou and, more generally, to the vicinity of source regions. The improved agreement of the AMF method results from the reintroduction of phyllosilicate mass into silt sizes through reaggregation, which has the effect of reducing the quartz fraction.

For feldspar, the AMF method reproduces the clay-size fraction of most measurements, in contrast to the SMF experiment, which omits feldspar at this size. At silt diameters, both experiments are consistent with the measurements, owing in part to their large uncertainty. 

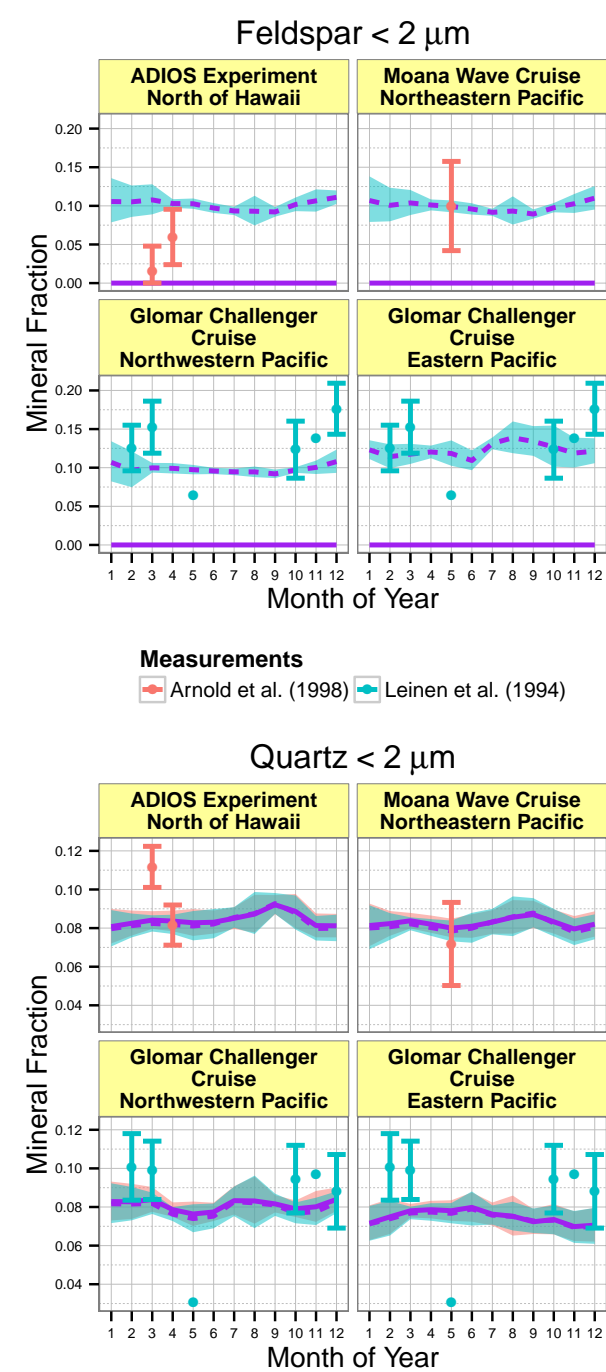

Figure 3. Same as Fig. 2 but for feldspar and quartz.

\subsection{Global evaluation of mineral fractions}

We summarize the model performance by comparison to a global distribution of measurements at silt and clay diameters, respectively (Figs. 4 and 5), as well as their sum over the entire model size range (the "bulk" composition: Fig. 6).

\subsubsection{Mineral fractions in the silt size range}

Figure 4 compares the measured and modeled fractions of phyllosilicate and quartz at silt sizes. The measurements cover various regions of the Northern Hemisphere, such as the northern and eastern Pacific (Leinen et al., 1994; Arnold et al., 1998), East Asia (Jeong et al., 2014), the Middle East (Ganor et al., 2000), the eastern Atlantic (Kandler et al., 2007), West Africa (Enete et al., 2012), and northwestern Africa (Kandler et al., 2009). Although there are fewer measurements restricted to the silt size range, compared to particle mass (PM) measurements that sum all diameters up to

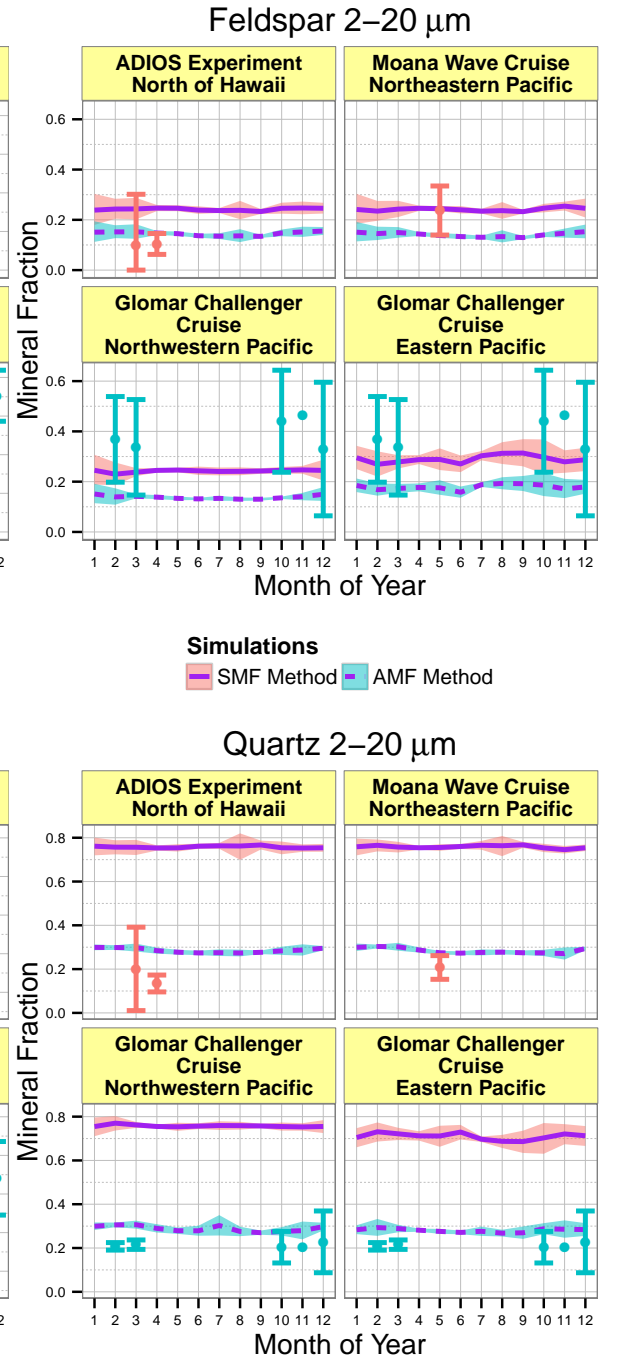

Feldspar 2-20 $\mu \mathrm{m}$

a prescribed limit, measurements of these particular minerals are relatively abundant.

At silt diameters, the SMF method systematically overestimates the observed quartz fraction while entirely excluding the phyllosilicates (Fig. 4, top row). As shown previously, this feature is largely corrected by the AMF method (Fig. 4, middle row), as clay-sized soil particles are reaggregated for emission at silt sizes at the expense of the quartz fraction. The importance of reaggregation to the improved performance of the AMF method is shown by the experiment where the reaggregation parameter $\gamma$ is set to zero (Fig. 4, bottom row). In the absence of reaggregation, quartz is overestimated and the phyllosilicates are underestimated, replicating the biases of the SMF experiment.

Even with reaggregation, the AMF method tends to underestimate illite at silt sizes, while overestimating kaolinite and smectite (the latter not shown). These errors could result from the mineral fractions prescribed by the MMT at silt 


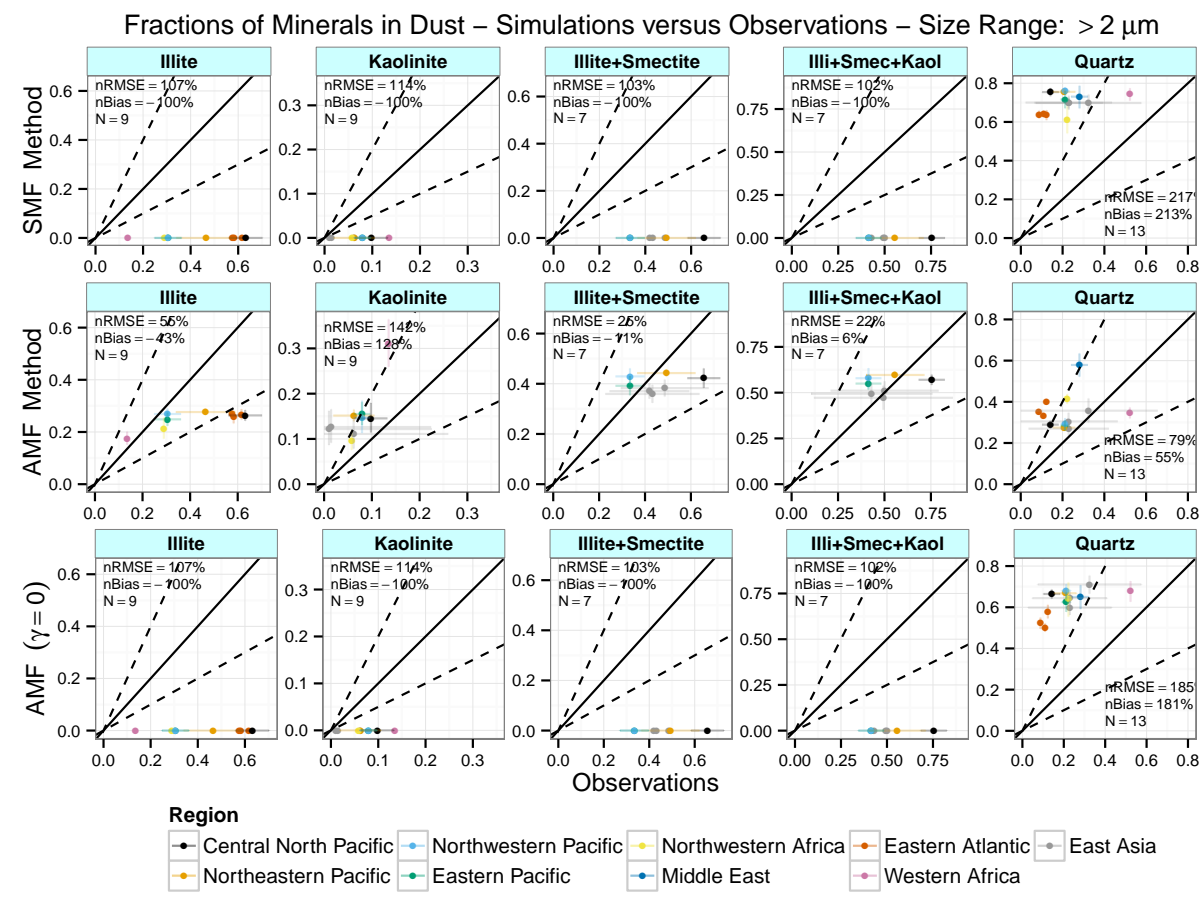

Figure 4. Scatterplot of mineral fractions of illite, kaolinite, the sum of illite and smectite, all phyllosilicates and quartz for silt particles (whose diameters are greater than $2 \mu \mathrm{m})$ simulated by the SMF, AMF and AMF $(\gamma=0)$ experiments vs. measurements. The dashed lines mark ratios of $2: 1$ and $1: 2$ between the simulated and observed mineral fractions. The horizontal and vertical error bars show the $95 \%$ confidence interval.

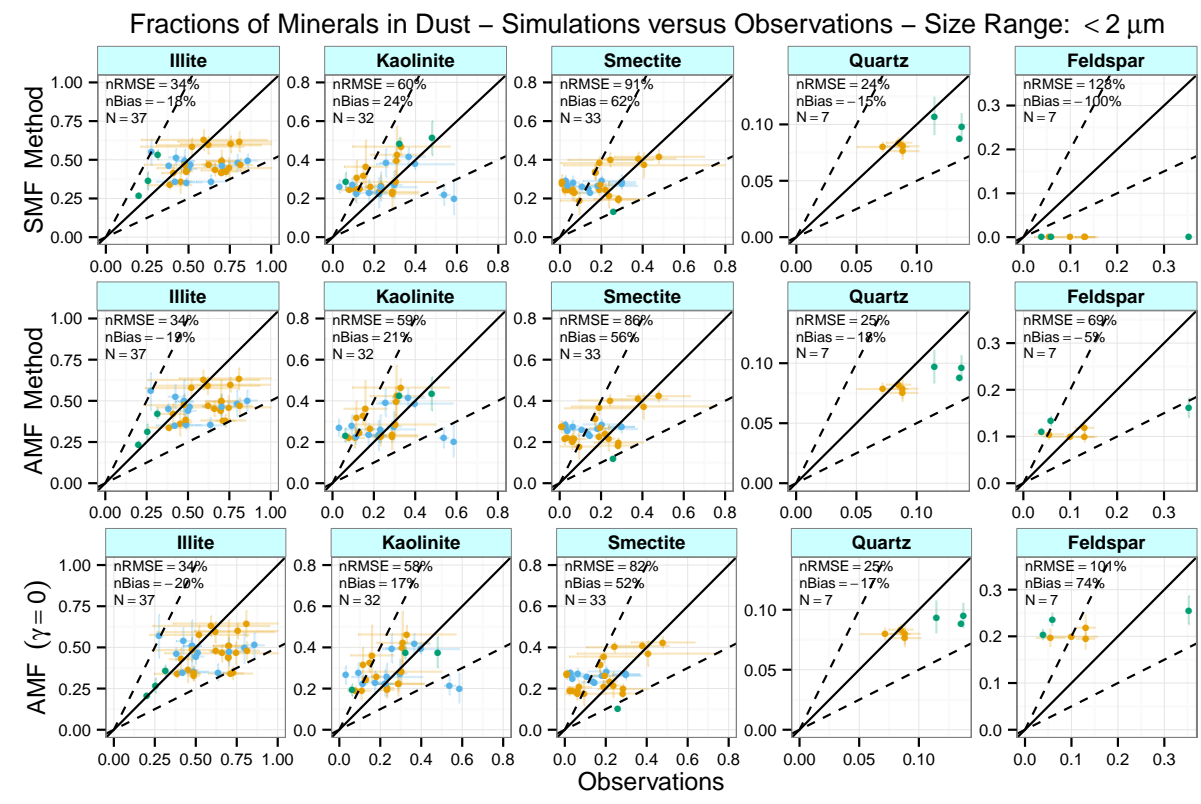

Distance to Source

$\rightarrow$ Long $\rightarrow$ Medium $\rightarrow$ Short

Figure 5. Same as Fig. 4 but for illite, kaolinite, smectite, quartz, and feldspar at clay diameters (less than $2 \mu \mathrm{m}$ ).

sizes, but also from the MMT clay fractions due to reaggre- gation. Combinations of illite with the other phyllosilicates show better agreement. 


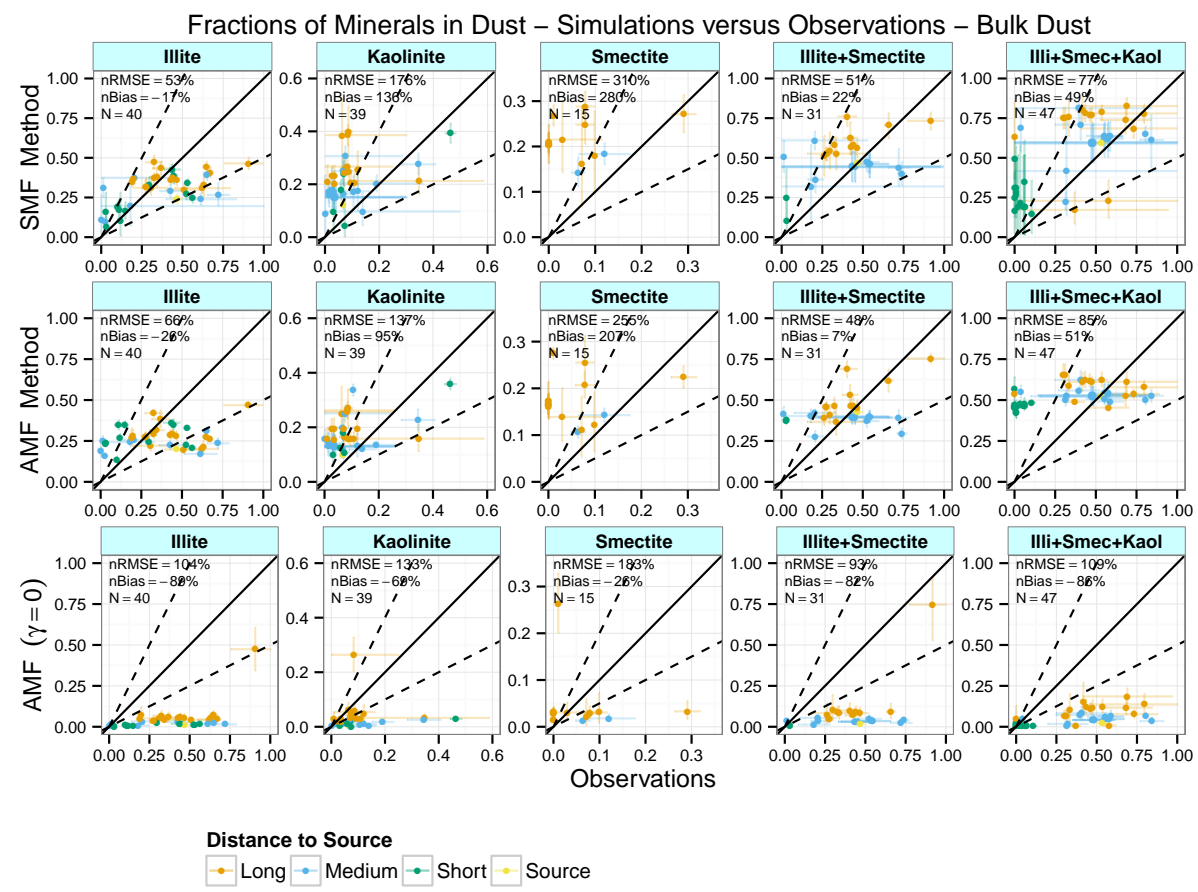

Figure 6. Same as Fig. 4 but for bulk (clay plus silt) mineral fractions of illite, kaolinite, smectite, the sum of illite and smectite, and all phyllosilicates.

\subsubsection{Mineral fractions in the clay size range}

Figure 5 shows that the compensating model biases in the silt fraction of the individual phyllosilicate minerals are also present at clay sizes. The number of phyllosilicate measurements at clay diameters is relatively large, suggesting that these biases are robust. Both experiments have similar phyllosilicate biases, reflecting their common dependence upon the MMT clay fraction. Errors in the MMT could result from the challenge of distinguishing individual phyllosilicate minerals in the soil samples, as suggested by the improved agreement of the combined phyllosilicate fraction. Alternatively, this challenge could result from errors and uncertainty in the aerosol measurements used to evaluate the model. Processes that are not represented in our model will also contribute to the bias. For example, the solubility of dust particles and their vulnerability to wet removal is assumed constant during transport, even though minerals like smectite (that are overestimated compared to illite) have a large hygroscopic capacity and take up water preferentially (Frinak et al., 2005).

All three experiments show good agreement of the quartz fraction at clay sizes (Fig. 5). Measurements also show that feldspar is present at this size despite its omission by the SMF method. The clay-sized feldspar in the AMF and AMF $(\gamma=0)$ experiments is calculated using the MMT silt fraction of this mineral along with the observed ratio of emitted clay to silt (Perlwitz et al., 2015, Eq. 14). The lower claysized fraction obtained with the AMF method, which is in better agreement with the few observations available, is ex- plained by the reduced fraction of silt-sized feldspar in this experiment due to the reaggregation of phyllosilicate mass into the silt-size range.

\subsubsection{Mineral fractions in bulk dust}

Bulk measurements of mineral composition represent sums over all particle sizes, and are plentiful compared to measurements within individual size categories. Both the SMF and AMF methods produce similar bulk fractions of phyllosilicates (Fig. 6), with a small negative bias for illite and a positive bias for kaolinite and smectite as previously noted for the individual clay and silt sizes. These biases compensate when the phyllosilicates are considered together (Fig. 6, rightmost column), but the simulated range of fractions remains underestimated by the AMF method.

With the exception of source regions and their vicinity, the AMF and SMF methods produce bulk fractions of both total phyllosilicates and quartz that are in good agreement with the measured values (Figs. 6 and 7). This agreement is in spite of clear biases in the SMF experiment at silt sizes (Fig. 4). In the companion article, it is shown that the SMF simulation emits less total dust (i.e., summed over all minerals) at silt diameters compared to the AMF method, while emitting more at clay sizes. Thus, the SMF method compensates for an excessive fraction of quartz at silt diameters with smaller silt emission. Similarly, the unrealistic restriction of phyllosilicates to clay sizes in the SMF experiments is offset by greater emission at these sizes. SMF fractional biases within individual 


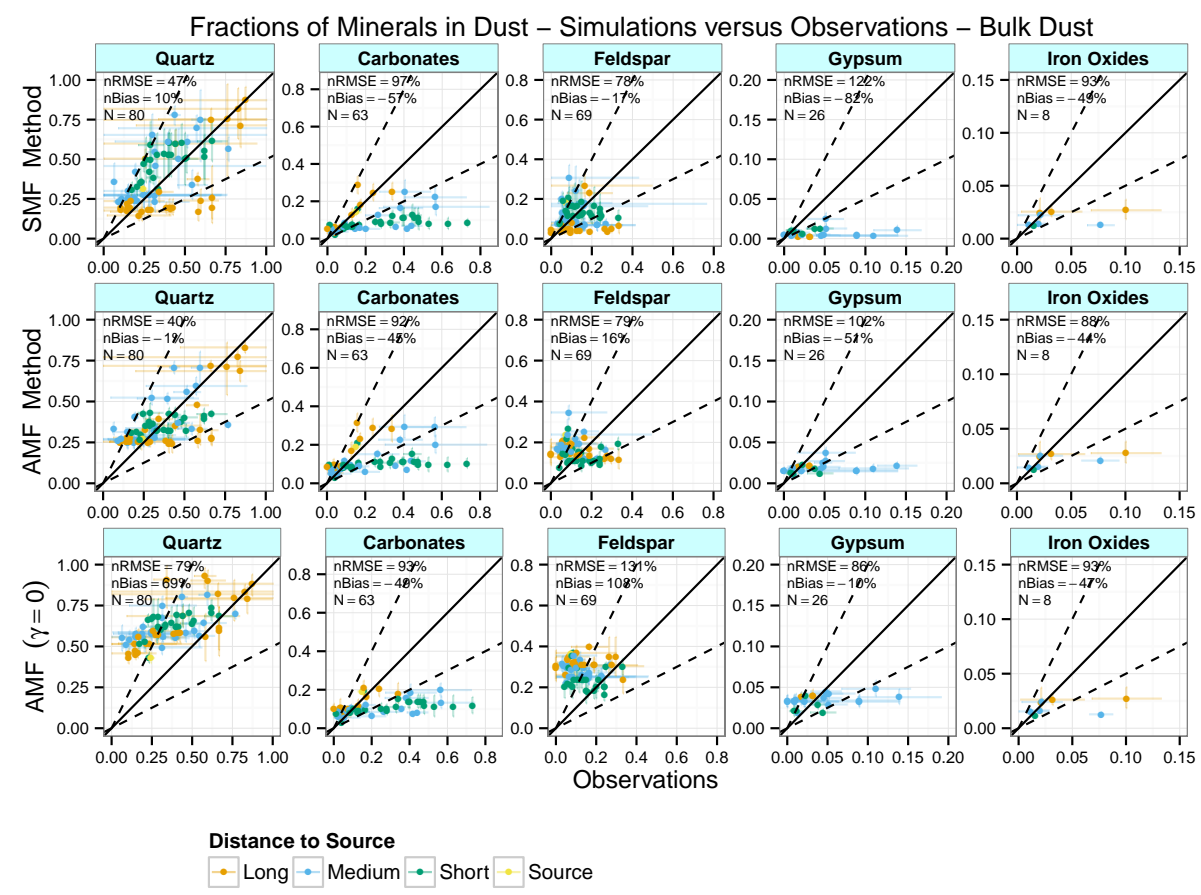

Figure 7. Same as Fig. 4 but for bulk mineral fractions of quartz, carbonates, feldspar, gypsum, and iron oxides.

size categories (Figs. 4 and 5) are hidden by bulk measurements due to the compensation of these errors.

This compensation is disabled in the AMF experiment with $\gamma=0$, showing the origin of the spurious agreement of the SMF method with the bulk measurements. For $\gamma=0$, reaggregation of phyllosilicate mass into the silt category is eliminated, resulting in an overestimated quartz fraction that is nearly identical to the SMF value at this size (Fig. 4). Consequently, the bulk measured value of the quartz fraction is overestimated (Fig. 7, bottom row), because the emitted silt fraction is large compared to the SMF method (albeit consistent with the AMF simulation and measurements).

Conversely, fractional emission at clay sizes for $\gamma=0$ is small compared to the SMF experiment, consistent with the default AMF experiment. As a result, the bulk fraction of phyllosilicates is underestimated for $\gamma=0$. This shows the compensating effect of enhanced emission at clay sizes in the SMF experiment that allows good agreement with the observed bulk mass of phyllosilicates, despite no emission at silt sizes.

All the experiments exhibit negative biases for their fractions of carbonates, gypsum, and iron oxide (Fig. 7). These minerals are a relatively small fraction of the soil according to the MMT, and the common model bias suggests that the MMT values may be an underestimate (although the uncertainty of these fractions is large due to limited measurements). The underestimate of iron oxides may additionally result from the exclusion of goethite by the MMT, a mineral that contributes over half of the measured iron oxide at some locations (Shi et al., 2012; Formenti et al., 2014a; Journet et al., 2014).

Measurements over the Arabian Peninsula (Al-Dousari and Al-Awadhi, 2012) indicate a negative bias of the carbonate fractions (Fig. 7, green dots) that may result from the model's truncated size range that is a poorer approximation near source regions, as discussed below.

\subsection{Ratios of mineral fractions}

The mineral fractions with respect to total dust that are analyzed in the previous section are unaffected by model errors in global emission. For consistency, we constructed the total dust mass using only minerals that are common to both the model and the specific measurement study. However, this construction introduces errors where measurements of total dust include minerals that are not reported. By considering ratios of specifc pairs of minerals, we avoid this ambiguity, even though distinguishing individual minerals can be more uncertain than measuring the total dust mass.

Figure 8 shows mineral ratios with respect to quartz, whose abundance allows relatively certain identification and measurement. Like mineral fractions, mineral ratios will evolve downwind of the source region. Within a single size bin, minerals that are denser or more soluble than quartz will decrease their ratio due to their larger gravitational settling speed or wet scavenging efficiency. In our model, we include only the first effect, and only pure crystalline iron oxides have a density that is appreciably different from that of quartz. With the exception of iron oxides, mineral ratios with 


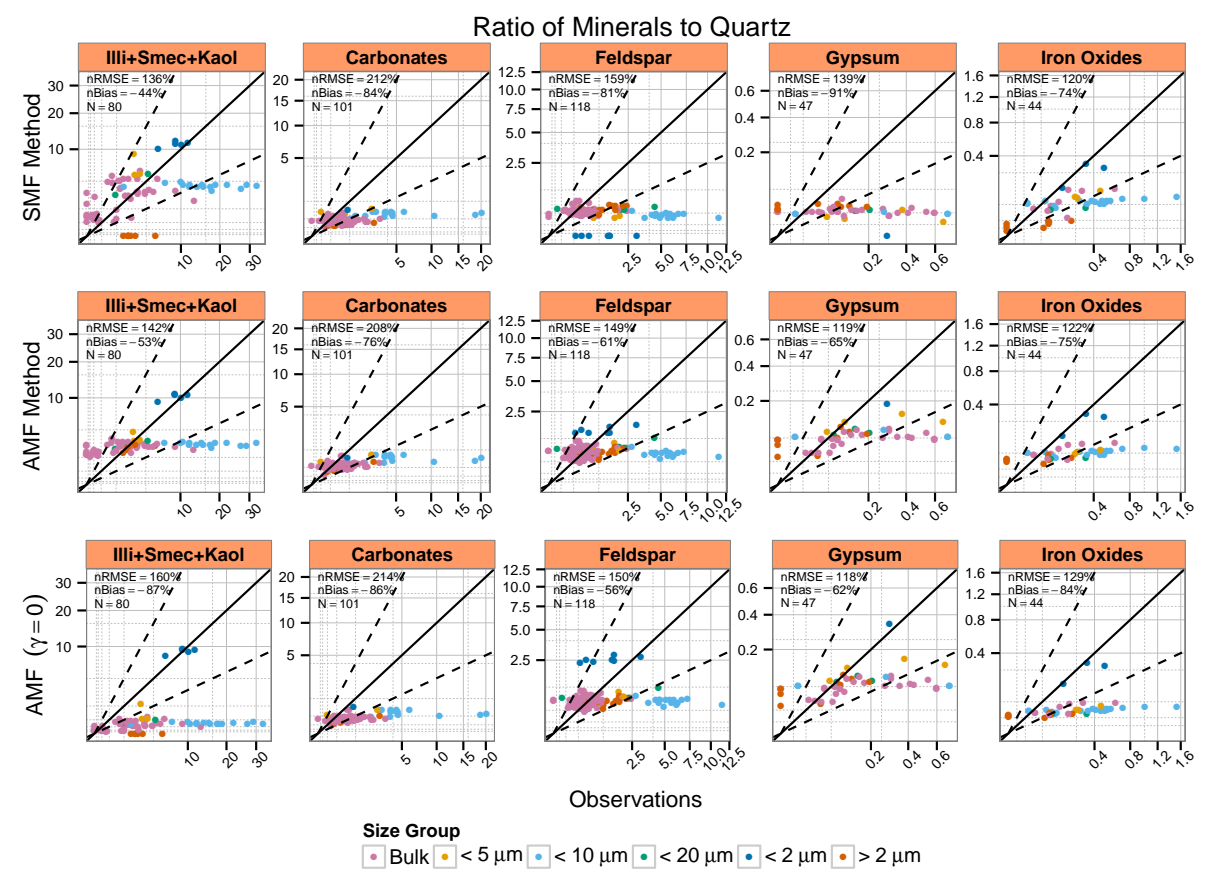

Figure 8. Measured vs. simulated mineral ratios with respect to quartz for the SMF, AMF and AMF $(\gamma=0)$ methods. The dashed lines mark a ratio of $2: 1$ and $1: 2$ between the simulated and observed mineral ratios.

respect to quartz are fairly constant within each size category. This ratio changes only as the relative contribution of different size bins to the mineral mass within the measured size range evolves downstream.

Figure 8 reiterates model behavior that was illustrated by the mineral fractions with respect to the total dust mass. For example, in the SMF experiment, phyllosilicates are absent outside of the clay size range, in contradiction to measurements (leftmost column, orange dots). This error is largely fixed in the AMF experiment. Again, this is a consequence of reaggregation, as shown by the AMF experiment with the reaggregation parameter $\gamma$ set to zero (bottom row), where the model phyllosilicate fraction is zero at purely silt diameters (orange dots). At clay sizes (dark blue dots), both experiments give similar fractions, reflecting their common derivation from the MMT. Similarly, feldspar and gypsum in the SMF experiment are absent at clay sizes (dark blue dots) as a direct result of the MMT.

Additional ratios with respect to minerals other than quartz are shown in Figs. S3 to S6 of the Supplement.

\subsection{Sources of model error}

The overestimated bulk fraction of combined phyllosilicates in the AMF experiment at various locations within the Arabian Peninsula (Fig. 6, middle row, right column, green points) illustrates potential sources of model error. The measurement sites are located near dust sources, where there are aerosols with large diameters outside the range transported by ModelE2. Al-Dousari and Al-Awadhi (2012) re- port that deposition at these sites is predominantly quartz and carbonate with roughly one-third of the total aerosol mass contributed by diameters above $63 \mu \mathrm{m}$. Overestimate of the phyllosilicate fraction at these locations could be caused by the model's exclusion of particle diameters above $32 \mu \mathrm{m}$ that causes the total model dust mass to be underestimated.

Figure 9, which compares mineral fractions within additional size ranges, illustrates other challenges of modeling mineral fractions near dust sources. All the simulations overestimate the quartz fraction of $\mathrm{PM}_{10}$ measured within the Middle East (left column, light blue dots) by Engelbrecht et al. (2009). This error is partly a consequence of apportioning emitted silt into the model size bins using measurements after transport. Preferential settling of the largest particles between the time of emission and measurement results in an underestimate of emission at this size. Correction of this error would reduce emission within the smaller silt categories that contribute to $\mathrm{PM}_{10}$. This is because the apportionment does not change the total silt emission, so that an increase at the largest size must be balanced by a reduction elsewhere. Both the SMF and AMF experiments are susceptible to errors of silt apportionment, but the overestimate of the $\mathrm{PM}_{10}$ quartz fraction is largest for the $\operatorname{AMF}(\gamma=0)$ experiment (Fig. 9, bottom row). This experiment combines the large quartz fraction of the SMF method (undiminished by phyllosilicate reaggregation) with the large fractional emission of silt diameters corresponding to the AMF method.

All the experiments consistently underestimate the range of observed mineral ratios (Fig. 8). This underestimate is 


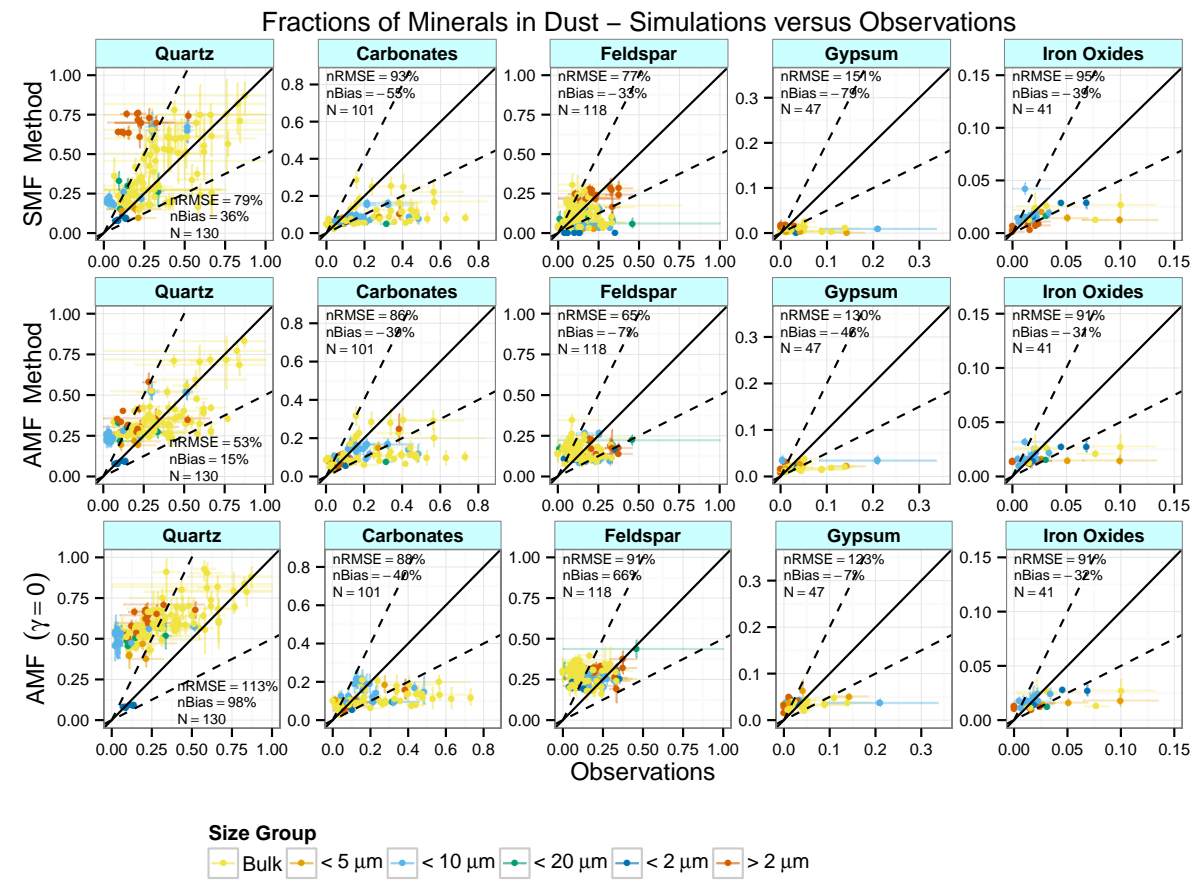

Figure 9. Same as Fig. 4 but including particle mass (PM) measurements at other size ranges.

partly a consequence of the MMT that is designed to give a mean mineral fraction that is approximately valid for all examples of a particular arid soil type instead of representing the actual variations within this soil type. The limited range may also result from the horizontal resolution of the model that prevents the reproduction of sharp gradients that are observed close to source regions, where the largest aerosols are removed rapidly by gravitational settling. The short lifetime of large particles results in measured spatial contrasts that are large and difficult to simulate, especially where the measurement sites are closely spaced, as in the study of Engelbrecht et al. (2009).

The single particle measurements of mineral fractions at Tinfou cannot distinguish the size distributions of the phyllosilicates and feldspars, which are thus assumed to be identical (Kandler et al., 2009). However, the increasing elemental ratio of potassium compared to silicon with increasing particle diameter suggests that feldspar is becoming more abundant compared to phyllosilicates within the model's largest transport bin. This suggests that the distribution of feldspar is in fact weighted toward larger silt sizes, in contrast to our current assumption that it shares an identical distribution with phyllosilicates. These corrections would have the greatest effect near source regions like the Arabian Peninsula (where the largest particles have not yet been depleted by gravitational settling) and for the AMF experiment, whose fractional emission of total dust at silt sizes is larger than the SMF fraction. The more general point is that near source re- gions, errors in our apportionment of silt emission have the largest effect.

\section{Conclusions}

In a companion article (Perlwitz et al., 2015), we define two methods of calculating aerosol mineral composition based upon the Mean Mineralogical Table (MMT) proposed by Claquin et al. (1999). The MMT infers the mineral composition of both the clay and silt-sized fractions of the soil at each location using a global atlas of arid soil type. For the Soil Mineral Fraction (SMF) method, we assume that the emitted size distribution corresponds to the local soil texture, so that the emitted mineral fractions and their dependence upon size are identical to those of the parent soil. Both the MMT and soil texture are based upon measurements that follow wet sieving of the soil sample, whereby soil aggregates are broken into smaller particles. Minerals like phyllosilicates that are aggregates of smaller soil particles are almost exclusively observed at clay sizes after wet sieving, despite aerosol measurements showing greater phyllosilicate mass at silt diameters (e.g., Kandler et al., 2009). This suggests that many of the aggregates that are destroyed during wet sieving would resist complete disintegration during wind erosion of the original, undispersed soil. We define a second experiment based upon the Aerosol Mineral Fraction (AMF) method that allows contrasts between the size distributions of the wet-sieved soil and the emitted minerals. We propose a heuristic reconstruction of aggregates based upon brittle 
fragmentation theory, where aggregrates of phyllosilicates and other minerals are reintroduced at silt sizes in proportion to their abundance at clay sizes in the wet-sieved soil. The emitted clay fraction is small, so that phyllosilicate aerosols in the AMF simulation are largely present at silt sizes as a result of reaggregation. The reintroduction of phyllosilicate aggregates at silt diameters reduces the emitted quartz fraction, because the fraction of emitted silt is fixed. Many of these aggregates are small enough to travel far from their source. However, the silt-sized mineral fractions of the wet-sieved soil include particles as large as $50 \mu \mathrm{m}$ that remain suspended only within a short distance from the parent soil. We specify the emitted fraction of each mineral at these larger diameters by using an empirical size distribution derived from measurements of dust arriving at Tinfou, Morocco. By accounting for these larger diameters, our study extends the method of Scanza et al. (2015), who also use brittle fragmentation theory to calculate emission of the far-traveled particles.

To evaluate the two experiments, we compiled measurements from nearly sixty studies that are distributed both near and far downwind of major dust source regions. In spite of this extensive compilation, many key sources remain undersampled. There are insufficient measurements to resolve the seasonal cycle of the mineral fractions and corroborate seasonal shifts of the dominant mineral calculated by the model that imply a change in source region. For example, kaolinite that is abundant in the Sahel dominates model deposition at Barbados during Northern Hemisphere winter, while an increase of emission in North Africa during the summer delivers more illite. In general, the uneven distribution of measurement sites and their limited duration imposes a large uncertainty that allows us to robustly evaluate only the most general features of the experiments.

Nonetheless, we show that the AMF method addresses key deficiencies of the SMF experiment in comparison to measurements. In particular, AMF phyllosilicates (that are nominally "clay" minerals) are most abundant at silt sizes, while the silt fraction of quartz is reduced compared to the SMF value and in better agreement with measurements. In spite of the unrealistic behavior of the SMF method at silt sizes, both experiments show reasonable agreement with measurements when the mineral fractions are summed over the entire size range. This is because the emitted clay fraction in the SMF experiment is large relative to the AMF experiment. This extra emission of clay-sized phyllosilicates in the SMF simulation compensates for the absence of these minerals at silt sizes. Similarly, the reduced fraction of emission at silt sizes in the SMF experiment compensates for its excessive quartz fraction. The fractional emission of clay and silt sizes in the SMF experiment is based upon the local soil texture that is derived from measurements of the fully dispersed, wet-sieved soil. However, the large fraction of emitted claysized particles in the SMF method is inconsistent with emission measurements that show a relatively small and regionally invariant emitted clay fraction (e.g., Kok, 2011). Thus, measurements of mineral fractions that sum over all sizes do not distinguish between the AMF and SMF methods because of compensating errors in the latter that are more clearly distinguished by measurements limited to silt diameters. This is shown by a variation of the AMF experiment with reaggregation omitted $(\gamma=0)$, where silt-sized phyllosilicates are absent and the mineral fractions compared poorly to bulk measurements.

The AMF method extends feldspar into the clay size range, consistent with measurements. However, the bulk mineral fractions of carbonates, gypsum and iron oxides are underestimated by both methods. The common bias suggests an origin within the MMT fractions, although the aerosol measurements themselves are infrequent and subject to uncertainty. The underestimation of iron oxides may also result from the exclusion of goethite from the MMT, a mineral that is a source of aerosol iron (Formenti et al., 2014a; Journet et al., 2014).

Both the SMF and AMF experiments reveal a smaller range of mineral ratios compared to the observations. This is partly a consequence of model resolution that is insufficient to resolve strong spatial contrasts in mineral fractions near isolated source regions. In addition, spatial variations of soil mineral composition are reduced by the MMT that consists of a single average value for all examples of the same arid soil type. Common features of the AMF and SMF mineral fractions at clay sizes are a useful test of the MMT, because the emitted fractions in both experiments are unmodified by reaggregation. Recent studies have proposed refinements to the MMT based upon a greater number of soil measurements and inclusion of additional minerals such as goethite, chlorite and vermiculite (Journet et al., 2014). These refinements can be complemented with studies that map the mineral composition of specific sources (Formenti et al., 2014b). However, we emphasize that there remain errors in our model representation of the aerosol life cycle.

Errors may also arise from our apportionment of the emitted silt to the transported size bins. The AMF method currently apportions silt emission using size-resolved measurements of individual minerals after transport to Tinfou, Morocco. Evaluation of the model mineral fractions suggests that prior deposition has preferentially removed the largest particles (cf. Fig. 17 of Perlwitz et al., 2015), resulting in an underestimate of emission at the largest silt sizes. This results in a compensating overestimate of emission at the smallest silt sizes (due to the normalization of the prescribed size distribution), contributing to excessive model values of $\mathrm{PM}_{10}$ near sources. Errors in the size distribution of emission have implications for the long-range transport of particular minerals like quartz that are typically emitted at larger sizes. This emphasizes the need for size-resolved measurements of emission that distinguish between individual minerals and can replace our current prescription based upon measurements after transport. 
This study is a step toward calculating the influence of aerosol mineral composition upon climate, including radiative forcing, physical and chemical transformation during transport and aerosol solubility, among other processes. While the global distributions of quartz and phyllosilicates like illite and kaolinite are probably the best characterized by measurements, other minerals with important climate impacts are subject to fewer constraints. This is especially true for minerals like montmorillonite (a member of the smectite group) and feldspar that are subject to fewer measurements, resulting in an uncertain spatial distribution despite these minerals' potential importance for ice nucleation (Hoose et al., 2008; Atkinson et al., 2013). Note that the regional distribution of smectite and feldspar are very different between the SMF and AMF experiments (cf. Figs. 14 and 15 of Perlwitz et al., 2015). Iron oxides are also subject to few direct measurements, either airborne or in the soil, although their distribution could be constrained using retrievals of aerosol shortwave absorption (Koven and Fung, 2006). In general, the climate impacts of dust that depend upon its specific mineral content remain highly uncertain and underconstrained.
Despite the extensive compilation of measurements presented in Table 1, the large remaining uncertainty limits our ability to suggest more precise treatments of aerosol mineral composition and its relation to the compositon of the parent soil. The abundant measurements of bulk mineral fractions far downwind of dust sources are particularly unhelpful to the extent that models can compensate for errors in soil composition through errors in the emitted size fraction. This shows the value of future measurements of aerosol mineral composition that are size resolved. Currently, these are rare, even though the technology exists for more routine sampling (e.g., Kandler et al., 2009). In contrast, measurements of elemental abundance are relatively ubiquitous and long records exist at stations like Izaña with relatively small sampling uncertainty (Rodríguez et al., 2011). We will report on an evaluation of the AMF and SMF methods using elemental abundance and the implications for modeling aerosol mineral composition in a subsequent study (Pérez García-Pando et al., 2015). 


\section{Appendix A: Sampling uncertainty}

We designed the evaluation of the SMF and AMF experiments to emphasize the differences between two methods of calculating aerosol mineral content. We compare mineral fractions rather than the absolute concentration of individual minerals to remove the effect of our uncertainty about the magnitude of global dust emission. Similarly, we relax the model winds toward reanalysis values so that the model mineral fractions are more strongly dependent upon the calculated fractions at emission rather than possible errors in aerosol transport.

Uncertainty of evaluation also results from sampling, including the occasional departure of the measurement duration from the monthly averages archived by the model. There are two general cases. In the first case, the measurements represent an average over a duration of a month or longer and can thus be compared directly with the archived model output. The measured quantity in this case is typically deposition. For this example, we calculate the standard deviation (SD) of the model, using the nine values available from the 9 years simulated by each experiment. The SD allows us to estimate a distribution of possible model values that can be compared to the single measured value. That is, we are asking whether the measured value is consistent with the model distribution. This allows a consistent treatment of measurements that are both within and beyond the range of years corresponding to our experiments. The model mean and SD of the mineral fractions are fitted to a beta distribution that is commonly used to represent values that are bounded between zero and one (e.g., Freund, 1992). In the figures, we illustrate the distribution of model values with the $95 \%$ confidence interval of the beta distribution.

In the second case, we have a measurement-like concentration whose duration is less than the single month used to archive model output. In most examples, we have multiple measurements from which we can estimate a time average and standard error for comparison to the model. If these measurements are confined to a single month, then we interpret the time average as an estimate of the monthly average that can be compared to the model output. The uncertainty of this average is estimated using the standard error $s_{\mathrm{E}, \mathrm{O}}$ :

$s_{\mathrm{E}, \mathrm{O}}=\frac{\sigma_{\mathrm{O}}}{\sqrt{N_{\mathrm{O}}}}$,

where $\sigma_{\mathrm{O}}$ is the $\mathrm{SD}$ of the $N_{\mathrm{O}}$ observations. (For computational convenience, we assume that the observations are distributed normally about their mean rather than according to a beta distribution. Then, the inferred time average of the observations is within 2 standard errors of the true value $95 \%$ of the time.) Here, we are essentially using the repeated observations to form a distribution of all possible values during the averaging interval, including those times when measurements were not taken. This distribution is then used to estimate the uncertainty of the mean. In the figures, this uncer- tainty is represented as 2 standard errors above and below the inferred time mean.

There are a few examples where daily measurements (or more generally, measurements over sub-monthly durations) are scattered over a much longer period. In some cases, the precise date of measurement is unknown (e.g., Engelbrecht et al., 2009). In these cases, the uncertainty of the corresponding time average is probably bounded by the annual cycle that we estimate using the SD of the measurements. Our uncertainty estimate is not particularly precise, but fortunately, there are relatively few cases of this type.

A more rare case is where we have a measurement for only a single day (e.g., Alastuey et al., 2005). Here we compare this single measurement directly to the monthly average of the model. We estimate the uncertainty of the single measurement as a monthly average by borrowing its SD from that calculated using the model. We cannot directly calculate the daily SD from model output, but we make the assumption that interannual variations in the model monthly means result solely from averaging over sub-monthly fluctuations. Then, we can estimate $\sigma_{\mathrm{M}}$, the model SD at the timescale of the observation interval $\Delta T_{\mathrm{O}}$ (1 day, in this example) according to

$\sigma_{\mathrm{M}}=\sqrt{\frac{N_{\mathrm{M}}}{\Delta T_{\mathrm{O}}}} \sigma_{\mathrm{M}, \text { monthly }}$,

where $\sigma_{\mathrm{M} \text {,monthly }}$ is the interannual SD of the monthly averages, and $N_{\mathrm{M}}$ represents the number of days in the month corresponding to the measurement. In the figure, the uncertainty is illustrated as 2 SDs above and below the single observed value.

There are a number of assumptions that go into our calculation of measurement uncertainty. For example, Eq. (A1) assumes that successive measurements are not correlated. It is straightforward to replace the number of observations with an effective number if the data show that successive measurements are autocorrelated (but we have neglected this possibility). In addition, the calculation of the sub-monthly SD in terms of interannual variability according to Eq. (A2) assumes that fluctuations of the mineral fractions have uniform spectral power at periods longer than the sub-monthly measurement interval. In general, our less defensible assumptions are necessitated by the sparse measurement record. This shows the urgent value of future measurements of aerosol mineral composition that are widespread and routine that would reduce the need for imprecise and heuristic characterizations of uncertainty like Eq. (A2). In any case, we try to draw conclusions from this study based upon differences between the experiments that are qualitatively apparent and that do not rely upon intricate statistical analysis. 


\section{The Supplement related to this article is available online at doi:10.5194/acp-15-11629-2015-supplement.}

Acknowledgements. We thank Paul Ginoux, Konrad Kandler, Jasper Kok, Natalie Mahowald, Sergio Rodríguez, Rachel Scanza and Yves Balkanski for helpful conversations. This article was improved by the thoughtful comments of the reviewers. This research was supported by the National Science Foundation (ATM-01-24258), the Department of Energy (DE-SC0006713), the NASA Modeling, Analysis and Prediction Program and the Ministry of Economy and Competitiveness of Spain through the POLLINDUST (CGL2011-26259). NCEP Reanalysis winds were provided by the Physical Sciences Division at the National Oceanic and Atmospheric Administration Earth System Research Laboratory via http://www.esrl.noaa.gov/psd/. Computational resources were provided by the NASA High-End Computing (HEC) Program through the NASA Center for Climate Simulation (NCCS) at Goddard Space Flight Center.

Edited by: Y. Balkanski

\section{References}

Adedokum, J. A., Emofurieta, W. O., and Adedeji, O. A.: Physical, Mineralogical and Chemical Properties of Harmattan Dust at Ile-Ife, Nigeria, Theor. Appl. Climatol., 40, 161-169, doi:10.1007/BF00866179, 1989.

Alastuey, A., Querol, X., Castillo, S., Escudero, M., Avila, A., Cuevas, E., Torres, C., Romero, P.-M., Exposito, F., García, O., Diaz, J. P., Van Dingenen, R., and Putaud, J. P.: Characterisation of TSP and PM2.5 at Izaña and Sta. Cruz de Tenerife (Canary Islands, Spain) during a Saharan Dust Episode (July 2002), Atmos. Environ., 39, 4715-4728, doi:10.1016/j.atmosenv.2005.04.018, 2005.

Al-Awadhi, J. M. and AlShuaibi, A. A.: Dust fallout in Kuwait city: Deposition and characterization, Sci. Total Environ., 461-462, 139-148, doi:10.1016/j.scitotenv.2013.03.052, 2013.

Al-Dousari, A. M. and Al-Awadhi, J.: Dust fallout in Northern Kuwait, major sources and characteristics, Kuwait J. Sci., 39, 171-187, 2012.

Al-Dousari, A. M., Al-Awadhi, J., and Ahmed, M.: Dust fallout characteristics within global dust storm major trajectories, Arab. J. Geosci., 6, 3877-3884, doi:10.1007/s12517-012-0644$0,2013$.

Alfaro, S. C. and Gomes, L.: Modeling mineral aerosol production by wind erosion: Emission intensities and aerosol size distributions in source areas, J. Geophys. Res., 106, 18075-18084, doi:10.1029/2000JD900339, 2001.

Arnold, E., Merrill, J., Leinen, M., and King, J.: The effect of source area and atmospheric transport on mineral aerosol collected over the North Pacific Ocean, Global Planet. Change, 18, 137-159, doi:10.1016/S0921-8181(98)00013-7, 1998.

Aston, S. R., Chester, R., Johnson, L. R., and Padgham, R. C.: Eolian Dust From The Lower Atmosphere Of The Eastern Atlantic And Indian Oceans, China Sea And Sea Of Japan, Marine Geol., 14, 15-28, doi:10.1016/0025-3227(73)90040-6, 1973.
Atkinson, J. D., Murray, B. J., Woodhouse, M. T., Whale, T. F., Baustian, K. J., Carslaw, K. S., Dobbie, S., O'Sullivan, D., and Malkin, T. L.: The importance of feldspar for ice nucleation by mineral dust in mixed-phase clouds, Nature, 498, 355-358, doi:10.1038/nature12278, 2013.

Avila, A., Queralt-Mitjans, I., and Alcarcón, M.: Mineralogical composition of African dust delivered by red rains over northeastern Spain, J. Geophys. Res., 102, 21977-21996, doi:10.1029/97JD00485, 1997.

Awadh, S. M.: Geochemistry and mineralogical composition of the airborne particles of sand dunes and dust storms settled in Iraq and their environmental impact, Environ. Earth. Sci., 66, 22472256, doi:10.1007/s12665-011-1445-6, 2012.

Baker, A. R., Laskina, O., and Grassian, V. H.: Processing and Ageing in the Atmosphere, in: Mineral Dust: A Key Player in the Earth System, edited by Knippertz, P. and Stuut, J.-B. W., chap. 4, pp. 75-92, Springer Netherlands, Dordrecht, Heidelberg, New York, London, doi:10.1007/978-94-017-8978-3_4, 2014.

Bauer, S. E. and Koch, D.: Impact of heterogeneous sulfate formation at mineral dust surfaces on aerosol loads and radiative forcing in the Goddard Institute for Space Studies general circulation model, J. Geophys. Res., 110, D17202, doi:10.1029/2005JD005870, 2005.

Cakmur, R. V., Miller, R. L., and Torres, O.: Incorporating the effect of small-scale circulations upon dust emission in an atmospheric general circulation model, J. Geophys. Res., 109, D07201, doi:10.1029/2003JD004067, 2004.

Caquineau, S., Gaudichet, A., Gomes, L., Magonthier, M., and Chatenet, B.: Saharan dust: Clay ratio as a relevant tracer to assess the origin of soil-derived aerosols, Geophys. Res. Lett., 25, 983-986, doi:10.1029/98GL00569, 1998.

Chester, R. and Johnson, L. R.: Atmospheric Dusts Collected off the Atlantic Coast of North Africa and the Iberian Peninsula, Marine Geol., 11, 251-260, doi:10.1016/0025-3227(71)90027-2, 1971a.

Chester, R. and Johnson, L. R.: Atmospheric Dust Collected Off the West African Coast, Nature, 229, 105-107, doi:10.1038/229105b0, 1971b.

Chester, R., Elderfield, H., and Griffin, J. J.: Dust transported in the North-east and South-east Trade Winds in the Atlantic Ocean, Nature, 233, 474-476, doi:10.1038/233474a0, 1971.

Chester, R., Elderfield, H., Griffin, J. J., Johnson, L., and Padgham, R. C.: Eolian dust along the eastern margins of the Atlantic Ocean, Marine Geol., 13, 91-105, doi:10.1016/00253227(72)90048-5, 1972.

Chester, R., Baxter, G. G., Behairy, A. K. A., Connor, K., Cross, D., Elderfield, H., and Padgham, R. C.: Soil-sized eolian dusts from the lower troposphere of the eastern Mediterranean Sea, Marine Geol., 24, 201-217, doi:10.1016/0025-3227(77)90028-7, 1977.

Chester, R., Sharples, E. J., Sanders, G. S., and Saydam, A. C.: Saharan Dust Incursion Over The Tyrrhenian Sea, Atmos. Environ., 18, 929-935, doi:10.1016/0004-6981(84)90069-6, 1984.

Choate, L. M., Ranville, J. F., Bunge, A. L., and Macalady, D. L.: Dermally adhered soil: 2 . Reconstruction of dry-sieve particlesize distributions from wet-sieve data, Int. Environ. Assess. Manage., 2, 385-390, doi:10.1002/ieam.5630020410, 2006.

Claquin, T., Schulz, M., and Balkanski, Y. J.: Modeling the mineralogy of atmospheric dust sources, J. Geophys. Res., 104, 22,24322,256, doi:10.1029/1999JD900416, 1999. 
Delany, A. C., Delany, A. C., Parkin, D. W., Griffin, J. J., Goldberg, E. D., and Reimann, B. E. F.: Airborne dust collected at Barbados, Geochim. Cosmochim. Ac., 31, 885-909, doi:10.1016/S0016-7037(67)80037-1, 1967.

Díaz-Hernández, J. L., Martín-Ramos, J. D., and López-Galindo, A.: Quantitative analysis of mineral phases in atmospheric dust deposited in the south-eastern Iberian Peninsula, Atmos. Environ., 45, 3015-3024, doi:10.1016/j.atmosenv.2011.03.024, 2011.

Enete, I. C., Obienusi, E. A., Igu, I. N., and Ayadiulo, R.: Harmattan Dust: Composition, Characteristics and Effects on Soil Fertility in Enugu, Nigeria, British J. Appl. Sci. Technol., 2, 72-81, doi:10.9734/BJAST/2012/950, 2012.

Engelbrecht, J. P., McDonald, E. V., Gillies, J. A., Jayanty, R. K. M., Casuccio, G., and Gertler, A. W.: Characterizing Mineral Dusts and Other Aerosols from the Middle East - Part 1: Ambient Sampling, Inhal. Toxicol., 21, 297-326, doi:10.1080/08958370802464273, 2009.

Engelbrecht, J. P., Menéndez, I., and Derbyshire, E.: Sources of $\mathrm{PM}_{2.5}$ impacting on Gran Canaria, Spain, CATENA, 117, 119132, doi:10.1016/j.catena.2013.06.017, 2014.

Falkovich, A. H., Ganor, E., Levin, Z., Formenti, P., and Rudich, Y.: Chemical and mineralogical analysis of individual mineral dust particles, J. Geophys. Res., 106, 18029-18036, doi:10.1029/2000JD900430, 2001.

FAO: Digital Soil Map of the World and Derived Soil Properties, Food and Agriculture Organization, Rome, Italy, 1995.

FAO: Digital Soil Map of the World, Food and Agriculture Organization, Rome, Italy, 2007.

FAO/IIASA/ISRIC/ISSCAS/JRC: Harmonized World Soil Database (version 1.2), FAO, Rome, Italy and IIASA, Laxenburg, Austria, http://webarchive.iiasa.ac.at/Research/LUC/ External-World-soil-database/HTML/HWSD_Data.html?sb=4 (last access: 24 January 2013), 2012.

Ferguson, W. S., Griffin, J. J., and Goldberg, E. D.: Atmospheric Dust from the North Pacific - A short note on a long range eolian transport, J. Geophys. Res., 75, 1137-1139, doi:10.1029/JC075i006p01137, 1970.

Fiol, L. A., Fornós, J. J., Gelabert, B., and Guijarro, J. A.: Dust rains in Mallorca (Western Mediterranean): Their occurrence and role in some recent geological processes, Catena, 63, 64-84, doi:10.1016/j.catena.2005.06.012, 2005.

Formenti, P., Rajot, J. L., Desboeufs, K., Caquineau, S., Chevaillier, S., Nava, S., Gaudichet, A., Journet, E., Triquet, S., Alfaro, S., Chiari, M., Haywood, J., Coe, H., and Highwood, E.: Regional variability of the composition of mineral dust from western Africa: Results from the AMMA SOP0/DABEX and DODO field campaigns, J. Geophys. Res., 113, D00C13, doi:10.1029/2008JD009903, 2008.

Formenti, P., Caquineau, S., Chevaillier, S., Klaver, A., Desboeufs, K., Rajot, J. L., Belin, S., and Briois, V.: Dominance of goethite over hematite in iron oxides of mineral dust from Western Africa: Quantitative partitioning by X-ray absorption spectroscopy, J. Geophys. Res., 119, 12740-12754, doi:10.1002/2014JD021668, 2014a.

Formenti, P., Caquineau, S., Desboeufs, K., Klaver, A., Chevaillier, S., Journet, E., and Rajot, J. L.: Mapping the physicochemical properties of mineral dust in western Africa: mineralogical composition, Atmos. Chem. Phys., 14, 10663-10686, doi:10.5194/acp-14-10663-2014, 2014b.
Freund, J. E.: Mathematical Statistics, Prentice Hall, Inc., Englewood Cliffs, New Jersey, 5th edn., 1992.

Frinak, E. K., Mashburn, C. D., Tolbert, M. A., and Toon, O. B.: Infrared characterization of water uptake by low-temperature $\mathrm{Na}$ montmorillonite: Implications for Earth and Mars, J. Geophys. Res., 110, D09308, doi:10.1029/2004JD005647, 2005.

Game, P. M.: Observations on a dustfall in the Eastern Atlantic, February, 1962, J. Sedimen. Petrol., 34, 355359, doi:10.1306/74D7105F-2B21-11D7-8648000102C1865D, 1964.

Ganor, E.: The composition of clay minerals transported to Israel as indicators of Saharan dust emission, Atmos. Environ., 25, 2657 2664, doi:10.1016/0960-1686(91)90195-D, 1991.

Ganor, E., Deutsch, Y., and Foner, H. A.: Mineralogical Composition and Sources of Airborne Settling Particles on Lake Kinneret (the Sea of Galilee), Israel, Water, Air, Soil Pollut., 118, 245262, doi:10.1023/A:1005167230795, 2000.

Gao, Y. and Anderson, J. R.: Characteristics of Chinese aerosols determined by individual-particle analysis, J. Geophys. Res., 106, 18037-18045, doi:10.1029/2000JD900725, 2001.

Gaudichet, A., Lefèvre, R., Gaudry, A., Ardouin, B., Lambert, G., and Miller, J. M.: Mineralogical composition of aerosols at Amsterdam Island, Tellus, 41, 344-352, doi:10.1111/j.16000889.1989.tb00313.x, 1989.

Gaudichet, A., Angclis, M. D., Joussaume, S., Petit, J. R., Korotkevitch, Y. S., and Petrov, V. N.: Comments on the origin of dust in East Antarctica for present and ice-age conditions, J. Atmos. Chem., 14, 192-142, doi:10.1007/BF00115229, 1992.

Ginoux, P., Chin, M., Tegen, I., Prospero, J. M., Holben, B., Dubovik, O., and Lin, S.-J.: Sources and distributions of dust aerosols simulated with the GOCART model, J. Geophys. Res., 106, 20255-20273, doi:10.1029/2000JD000053, 2001.

Glaccum, R. A. and Prospero, J. M.: Saharan aerosols over the tropical North Atlantic - Mineralogy, Marine Geol., 37, 295-321, doi:10.1016/0025-3227(80)90107-3, 1980.

Goldberg, E. D. and Griffin, J. J.: The sediments of the Northern Indian Ocean, Deep Sea Res., 17, 513-537, doi:10.1016/00117471(70)90065-3, 1970.

Grini, A., Zender, C. S., and Colarco, P. R.: Saltation Sandblasting behavior during mineral dust aerosol production, Geophys. Res. Lett., 29, 1868, doi:10.1029/2002GL015248, 2002.

Hoose, C., Lohmann, U., Erdin, R., and Tegen, I.: The global influence of dust mineralogical composition on heterogeneous ice nucleation in mixed-phase clouds, Environ. Res. Lett., 3, 025003 , doi:10.1088/1748-9326/3/2/025003, 2008.

Iversen, J. D. and White, B. R.: Saltation threshold on Earth, Mars and Venus, Sedimentology, 29, 111-119, doi:10.1111/j.13653091.1982.tb01713.x, 1982.

Jeong, G. Y.: Bulk and single-particle mineralogy of Asian dust and a comparison with its source soils, J. Geophys. Res., 113, D02208, doi:10.1029/2007JD008606, 2008.

Jeong, G. Y. and Achterberg, E. P.: Chemistry and mineralogy of clay minerals in Asian and Saharan dusts and the implications for iron supply to the oceans, Atmos. Chem. Phys., 14, 1241512428, doi:10.5194/acp-14-12415-2014, 2014.

Jeong, G. Y., Kim, J. Y., Seo, J., Kim, G. M., Jin, H. C., and Chun, Y.: Long-range transport of giant particles in Asian dust identified by physical, mineralogical, and meteorological analysis, At- 
mos. Chem. Phys., 14, 505-521, doi:10.5194/acp-14-505-2014, 2014.

Johnson, L. R.: Particle-Size Fractionation of Eolian Dust During Transport and Sampling, Marine Geology, 21, M17-M21, doi:10.1016/0025-3227(76)90099-2, 1976.

Journet, E., Balkanski, Y., and Harrison, S. P.: A new data set of soil mineralogy for dust-cycle modeling, Atmos. Chem. Phys., 14, 3801-3816, doi:10.5194/acp-14-3801-2014, 2014.

Kalnay, E., Kanamitsu, M., Kistler, R., Collins, W., Deaven, D., Gandin, L., Iredell, M., Saha, S., White, G., Woollen, J., Zhu, Y., Leetmaa, A., Reynolds, R., Chelliah, M., Ebisuzaki, W., Higgins, W., Janowiak, J., Mo, K. C., Ropelewski, C., Wang, J., Jenne, R., and Joseph, D.: The NCEP/NCAR 40-Year Reanalysis Project, B. Am. Meteorol. Soc., 77, 437-471, doi:10.1175/15200477(1996)077<0437:TNYRP>2.0.CO;2, 1996.

Kandler, K., Benker, N., Bundke, U., Cuevas, E., Ebert, M., Knippertz, P., Rodríguez, S., Schütz, L., and Weinbruch, S.: Chemical composition and complex refractive index of Saharan Mineral Dust at Izanã, Tenerife (Spain) derived by electron microscopy, Atmos. Environ., 41, 8058-8074, doi:10.1016/j.atmosenv.2007.06.047, 2007.

Kandler, K., Schütz, L., Deutscher, C., Ebert, M., Hofmann, H., Jäckel, S., Jaenicke, R., Knippertz, P., Lieke, K., Massling, A., Petzold, A., Schladitz, A., Weinzierl, B., Wiedensohler, A., Zorn, S., and Weinbruch, S.: Size distribution, mass concentration, chemical and mineralogical composition and derived optical parameters of the boundary layer aerosol at Tinfou, Morocco, during SAMUM 2006, Tellus B, 61, 32-50, doi:10.1111/j.16000889.2008.00385.x, 2009.

Kandler, K., Schütz, L., Jäckel, S., Lieke, K., Emmel, C., MüllerEbert, D., Ebert, M., Scheuvens, D., Schladitz, A., Šegvić, B., Wiedensohler, A., and Weinbruch, S.: Ground-based offline aerosol measurements at Praia, Cape Verde, during the Saharan Mineral Dust Experiment: microphysical properties and mineralogy, Tellus B, 63, 459-474, doi:10.1111/j.16000889.2011.00550.x, 2011.

Khalaf, F. I., Al-Kadi, A., and Al-Saleh, S.: Mineralogical composition and potential sources of dust fallout deposits in Kuwait, northern Arabian Gulf, Sedimentary Geol., 42, 255-278, doi:10.1016/0037-0738(85)90047-8, 1985.

Klaver, A., Formenti, P., Caquineau, S., Chevaillier, S., Ausset, P., Calzolai, G., Osborne, S., Johnson, B., Harrison, M., and Dubovik, O.: Physico-chemical and optical properties of Sahelian and Saharan mineral dust: in situ measurements during the GERBILS campaign, Q. J. Roy. Meteorol. Soc., 137, 1193-1210, doi:10.1002/qj.889, 2011.

Koch, D., Jacob, D., Tegen, I., Rind, D., and Chin, M.: Tropospheric sulfur simulation and sulfate direct radiative forcing in the Goddard Institute for Space Studies general circulation model, J. Geophys. Res., 104, 23799-23822, doi:10.1029/1999JD900248, 1999.

Kok, J. F.: A scaling theory for the size distribution of emitted dust aerosols suggests climate models underestimate the size of the global dust cycle, P. Natl. Acad. Sci. USA, 108, 1016-1021, doi:10.1073/pnas.1014798108, 2011.

Koven, C. D. and Fung, I.: Inferring dust composition from wavelength-dependent absorption in Aerosol Robotic Network (AERONET) data, J. Geophys. Res., 111, D14205, doi:10.1029/2005JD006678, 2006.
Lafon, S., Sokolik, I. N., Rajot, J. L., Caquineau, S., and Gaudichet, A.: Characterization of iron oxides in mineral dust aerosols: Implications for light absorption, J. Geophys. Res., 111, D21207, doi:10.1029/2005JD007016, 2006.

Laurent, B., Marticorena, B., Bergametti, G., Léon, J. F., and Mahowald, N. M.: Modeling mineral dust emissions from the Sahara desert using new surface properties and soil database, J. Geophys. Res.-Atmos. (1984-2012), 113, D14218, doi:10.1029/2007JD009484, 2008.

Leinen, M., Prospero, J. M., Arnold, E., and Blank, M.: Mineralogy of aeolian dust reaching the North Pacific Ocean 1. Sampling and analysis, J. Geophys. Res., 99, 21017-21023, doi:10.1029/94JD01735, 1994.

Lu, S., Shao, L., Wu, M., and Jiao, Z.: Mineralogical characterization of airborne individual particulates in Bejing $P M_{10}$, J. Environ. Sci., 18, 90-95, 2006.

McFadden, L. D. and Hendricks, D. M.: Changes in the content and composition of pedogenic iron oxyhydroxides in a chronosequence of soils in southern California, Quat. Res., 23, 189-204, doi:10.1016/0033-5894(85)90028-6, 1985.

Menéndez, I., Díaz-Hernández, J. L., Mangas, J., Alonso, I., and Sánchez-Soto, P. J.: Airborne dust accumulation and soil development in the North-East sector of Gran Canaria (Canary Islands, Spain), J. Arid Environ., 71, 57-81, doi:10.1016/j.jaridenv.2007.03.011, 2007.

Miller, R. L., Cakmur, R. V., Perlwitz, J., Geogdzhayev, I. V., Ginoux, P., Koch, D., Kohfeld, K. E., Prigent, C., Ruedy, R., Schmidt, G. A., and Tegen, I.: Mineral dust aerosols in the NASA Goddard Institute for Space Sciences ModelE atmospheric general circulation model, J. Geophys. Res., 111, D06208, doi:10.1029/2005JD005796, 2006.

Møberg, J. P., Esu, I. E., and Malgwi, W. B.: Characteristics and constituent composition of Harmattan dust falling in Northern Nigeria, Geoderma, 48, 73-81, doi:10.1016/00167061(91)90007-G, 1991.

Moulin, C., Lambert, C. E., Dulac, F., and Dayan, U.: Control of atmospheric export of dust from North Africa by the North Atlantic Oscillation, Nature, 387, 691-694, 1997.

Navea, J. G., Chen, H., Huang, M., Carmichael, G. R., and Grassian, V. H.: A comparative evaluation of water uptake on several mineral dust sources, Environ. Chem., 7, 162-170, doi:10.1071/EN09122, 2010.

Nickovic, S., Vukovic, A., Vujadinovic, M., Djurdjevic, V., and Pejanovic, G.: Technical Note: High-resolution mineralogical database of dust-productive soils for atmospheric dust modeling, Atmos. Chem. Phys., 12, 845-855, doi:10.5194/acp-12-8452012, 2012.

NRCS Soil Survey Staff: U.S. General Soil Map (STATSGO), Natural Resources Conservation Service, United States Department of Agriculture, available at: http://sdmdataaccess.nrcs.usda.gov/ (last access: 11 April 2013), 2012.

O'Hara, S. L., Clarke, M. L., and Elatrash, M. S.: Field measurements of desert dust deposition in Libya, Atmos. Environ., 40, 3881-3897, doi:10.1016/j.atmosenv.2006.02.020, 2006.

Parkin, D. W., Phillips, D. R., Sullivan, R. A. L., and Johnson, L.: Airborne dust collections over the North Atlantic, J. Geophys. Res., 75, 1782-1793, doi:10.1029/JC075i009p01782, 1970. 
Parkin, D. W., Phillips, D. R., Sullivan, R., and Johnson, L.: Airborne dust collections down the Atlantic, Q. J. Roy. Meteorol. Soc., 98, 798-808, doi:10.1002/qj.49709841807, 1972.

Pérez García-Pando, C., Perlwitz, J. P., Miller, R. L., and Rodriguez, S.: Predicting the mineral composition of dust aerosols: Insights from chemical composition measurements at the Izaña Observatory, Geophys. Res. Lett., in preparation, 2015.

Perlwitz, J. P., Pérez García-Pando, C., and Miller, R. L.: Predicting the mineral composition of dust aerosols - Part 1: Representing key processes, Atmos. Chem. Phys., 15, 11593-11627, doi:10.5194/acp-15-11593-2015, 2015.

Prigent, C., Tegen, I., Aires, F., Marticorena, B., and Zribi, M.: Estimation of the aerodynamic roughness length in arid and semiarid regions over the globe with the ERS scatterometer, J. Geophys. Res., 110, D09205, doi:10.1029/2004JD005370, 2005.

Prospero, J. M. and Bonatti, E.: Continental Dust in the Atmosphere of the Eastern Equatorial Pacific, J. Geophys. Res., 74, 33623371, doi:10.1029/JC074i013p03362, 1969.

Prospero, J. M., Glaccum, R. A., and Nees, R. T.: Atmospheric transport of soil dust from Africa to South America, Nature, 289, 570-572, doi:10.1038/289570a0, 1981.

Prospero, J. M., Ginoux, P., Torres, O., Nicholson, S. E., and Gill, T. E.: Environmental characterization of global sources of atmospheric soil dust identified with the Nimbus 7 Total Ozone Mapping Spectrometer (TOMS) absorbing aerosol product, Rev. Geophys., 40, 2-1-2-31, doi:10.1029/2000RG000095, 2002.

Queralt-Mitjans, I., Domingo, F., and Sole-Benet, A.: The influence of local sources on the mineral content of bulk deposition over an altitudinal gradient in the Filabres Range (SE Spain), J. Geop., 98, 16761-16768, doi:10.1029/93JD01281, 1993.

Rashki, A., Eriksson, P. G., de W. Rautenbach, C. J., Kaskaoutis, D. G., Grote, W., and Dykstra, J.: Assessment of chemical and mineralogical characteristics of airborne dust in the Sistan region, Iran, Chemosphere, 90, 227-236, doi:10.1016/j.chemosphere.2012.06.059, 2013.

Rayner, N. A., Parker, D. E., Horton, E. B., Folland, C. K., Alexander, L. V., Rowell, D. P., Kent, E. C., and Kaplan, A.: Global analyses of sea surface temperature, sea ice, and night marine air temperature since the late nineteenth century, J. Geophys. Res., 108, 4407, doi:10.1029/2002JD002670, 2003.

Rodríguez, S., Alastuey, A., Alonso-Pérez, S., Querol, X., Cuevas, E., Abreu-Afonso, J., Viana, M., Pérez, N., Pandolfi, M., and de la Rosa, J.: Transport of desert dust mixed with North African industrial pollutants in the subtropical Saharan Air Layer, Atmos. Chem. Phys., 11, 6663-6685, doi:10.5194/acp-11-66632011, 2011.

Scanza, R. A., Mahowald, N., Ghan, S., Zender, C. S., Kok, J. F., Liu, X., Zhang, Y., and Albani, S.: Modeling dust as component minerals in the Community Atmosphere Model: development of framework and impact on radiative forcing, Atmos. Chem. Phys., 15, 537-561, doi:10.5194/acp-15-537-2015, 2015.

Scheuvens, D. and Kandler, K.: On Composition, Morphology, and Size Distribution of Airborne Mineral Dust, in: Mineral Dust: A Key Player in the Earth System, edited by: Knippertz, P. and Stuut, J.-B., chap. 2, p. 15-49, Springer Netherlands, Dordrecht, Heidelberg, New York, London, doi:10.1007/978-94-017-89783_2, 2014 .

Scheuvens, D., Schütz, L., Kandler, K., Ebert, M., and Weinbruch, S.: Bulk composition of northern African dust and its source sed- iments and its source sediments - A compilation, Earth-Sci. Rev., 116, 170-194, doi:10.1016/j.earscirev.2012.08.005, 2013.

Schmidt, G. A., Ruedy, R., Hansen, J. E., Aleinov, I., Bell, N., Bauer, M., Bauer, S., Cairns, B., Canuto, V., Ye Cheng, A. D., Faluvegi, G., Friend, A. D., Hall, T. M., Hu, Y., Kelley, M., Kiang, N. Y., Koch, D., Andy A. Lacis, J. L., Lo, K. K., Miller, R. L., Nazarenko, L., Oinas, V., Perlwitz, J., Rind, J. P. D., Romanou, A., Gary L. Russell, M. S., Shindell, D. T., Stone, P. H., Sun, S., Tausnev, N., Thresher, D., and Yao, M.-S.: Present-Day Atmospheric Simulations Using GISS ModelE: Comparison to In Situ, Satellite, and Reanalysis Data, J. Climate, 19, 153-192, doi:10.1175/JCLI3612.1, 2006.

Schmidt, G. A., Kelley, M., Nazarenko, L., Ruedy, R., Russell, G. L., Aleinov, I., Bauer, M., Bauer, S. E., Bhat, M. K., Bleck, R., Canuto, V., Chen, Y.-H., Cheng, Y., Clune, T. L., Del Genio, A., de Fainchtein, R., Faluvegi, G., Hansen, J. E., Healy, R. J., Kiang, N. Y., Koch, D., Lacis, A. A., LeGrande, A. N., Lerner, J., Lo, K. K., Matthews, E. E., Menon, S., Miller, R. L., Oinas, V., Oloso, A. O., Perlwitz, J. P., Puma, M. J., Putman, W. M., Rind, D., Romanou, A., Sato, M., Shindell, D. T., Sun, S., Syed, R. A., Tausnev, N., Tsigaridis, K., Unger, N., Voulgarakis, A., Yao, M.S., and Zhang, J.: Configuration and assessment of the GISS ModelE2 contributions to the CMIP5 archive, J. Adv. Model. Earth Sys., 6, 141-184, doi:10.1002/2013MS000265, 2014.

Shao, L., Li, W., Xiao, Z., and Sun, Z.: The mineralogy and possible sources of spring dust particles over Bejing, Adv. Atmos. Sci. 25, 395-403, doi:10.1007/s00376-008-0395-8, 2008.

Shao, Y.: A model for mineral dust emission, J. Geophys. Res., 106, 20239-20254, doi:10.1029/2001JD900171, 2001.

Shao, Y., Raupach, M. R., and Leys, J. F.: A model for predicting aeolian sand drift and dust entrainment on scales from paddock to region, Aust. J. Soil Res., 34, 309-342, doi:10.1071/SR9960309, 1996.

Shen, Z., Cao, J., Li, X., Okuda, T., Wang, Y., and Wang, X.: Mass concentration and mineralogical characteristics of aerosol particles collected at Dunhuang during ACE-Asia, Adv. Atmos. Sci., 23, 291-298, doi:10.1007/s00376-006-0291-z, 2006.

Shen, Z., Caquineau, S., Cao, J., Zhang, X., Han, Y., Gaudichet, A., and Gomes, L.: Mineralogical characteristics of soil dust from source regions in northern China, Particuology, 7, 507-512, doi:10.1016/j.partic.2009.10.001, 2009.

Shi, Z., Shao, L., Jones, T. P., and Lu, S.: Microscopy and mineralogy of airborne particles collected during severe dust storm episodes in Beijing, China, J. Geophys. Res., 110, D01303, doi:10.1029/2004JD005073, 2005.

Shi, Z., Krom, M. D., Bonneville, S., Baker, A. R., Bristow, C., Drake, N., Mann, G., Carslaw, K., McQuaid, J. B., Jickells, T., and Benning, L. G.: Influence of chemical weathering and aging of iron oxides on the potential iron solubility of Saharan dust during simulated atmospheric processing, Global Biogeochem. Cycles, 25, GB2010, doi:10.1029/2010GB003837, 2011.

Shi, Z., Krom, M. D., Jickells, T. D., Bonneville, S., Carslaw, K. S., Mihalopoulos, N., Baker, A. R., and Benning, L. G.: Impacts on iron solubility in the mineral dust by processes in the source region and the atmosphere: A review, Aeolian Res., 5, 21-42, doi:10.1016/j.aeolia.2012.03.001, 2012.

Skonieczny, C., Bory, A., Bout-Roumazeilles, V., Abouchami, W., Galer, S. J. G., Crosta, X., Stuut, J., Meyer, I., Chiapello, I., Podvin, T., Chatenet, B., Diallo, A., and Ndiaye, T.: The 713 March 
2006 major Saharan outbreak: Multiproxy characterization of mineral dust deposited on the West African margin, J. Geophys. Res., 116, D18210, doi:10.1029/2011JD016173, 2011.

Skonieczny, C., Bory, A., Bout-Roumazeilles, V., Abouchami, W., Galer, S. J. G., Crosta, X., Diallo, A., and Ndiaye, T.: A threeyear time series of mineral dust deposits on the West African margin: Sedimentological and geochemical signatures and implications for interpretation of marine paleo-dust records, Earth Planet. Sci. Lett., 364, 145-156, doi:10.1016/j.eps1.2012.12.039, 2013.

Sŕodoń, J.: Nature of mixed-layer clays and mechanisms of their formation and alteration, Annu. Rev. Earth Planet. Sci., 27, 1953, doi:10.1146/annurev.earth.27.1.19, 1999.

Tegen, I. and Fung, I.: Modeling of mineral dust in the atmosphere: Sources, transport, and optical thickness, J. Geophys. Res., 99, 22897-22914, doi:10.1029/94JD01928, 1994.

Tomadin, L., Lenaz, R., Landuzzi, V., Mazzucotelli, A., and Vannucci, R.: Wind-blown dust over the Central Mediterranean, Oceanologica Ac., 7, 13-23, 1984.
Wesely, M. L. and Hicks, B. B.: Some factors that affect the deposition rates of sulfur dioxide and similar gases on vegetation, J. Air Pollut. Control Assoc., 27, 1110-1116, doi:10.1080/00022470.1977.10470534, 1977.

Windom, H. L.: Atmospheric Dust Records in Permanent Snowfields: Implications to Marine Sedimentation, Geol. Soc. Amer. Bull., 80, 761-782, doi:10.1130/00167606(1969)80[761:ADRIPS]2.0.CO;2, 1969.

Zdanowicz, C., Hall, G., Vaive, J., Amelin, Y., Percival, J., Girard, I., Biscaye, P., and Bory, A.: Asian dustfall in the St. Elias Mountains, Yukon, Canada, Geochim. Cosmochim. Ac., 70, 3493 3507, doi:10.1016/j.gca.2006.05.005, 2006.

Zhou, G. and Tazaki, K.: Seasonal variation of gypsum in aerosol and its effect on the acidity of wet precipitation on the Japan Sea side of Japan, Atmos. Environ., 30, 3301-3308, doi:10.1016/1352-2310(96)00071-4, 1996. 